\title{
Conceptual Safety Design Report for the Remote-Handled Low-Level Waste Disposal Facility
}

February 2010

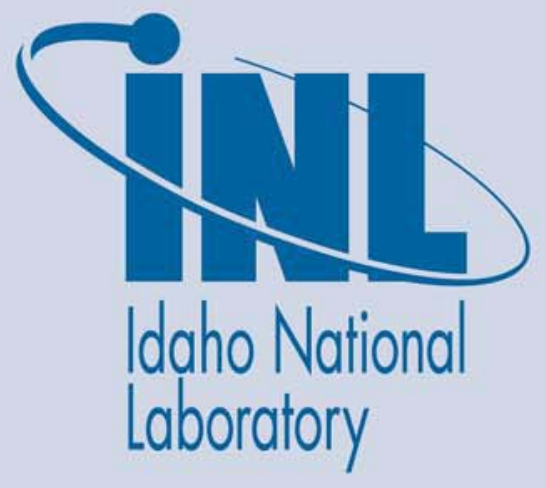

The INL is a U.S. Department of Energy National Laboratory operated by Battelle Energy Alliance 
INL/EXT-09-17427

\title{
Conceptual Safety Design Report for the Remote- Handled Low-Level Waste Disposal Facility
}

February 2010

\author{
Idaho National Laboratory \\ Idaho Falls, Idaho 83415
}

http://www.inl.gov

Prepared for the

U.S. Department of Energy

Office of Nuclear Energy

Under DOE Idaho Operations Office

Contract DE-AC07-05ID14517 


\section{DISCLAIMER}

This information was prepared as an account of work sponsored by an agency of the U.S. Government. Neither the U.S. Government nor any agency thereof, nor any of their employees, makes any warranty, expressed or implied, or assumes any legal liability or responsibility for the accuracy, completeness, or usefulness, of any information, apparatus, product, or process disclosed, or represents that its use would not infringe privately owned rights. References herein to any specific commercial product, process, or service by trade name, trade mark, manufacturer, or otherwise, does not necessarily constitute or imply its endorsement, recommendation, or favoring by the U.S. Government or any agency thereof. The views and opinions of authors expressed herein do not necessarily state or reflect those of the U.S. Government or any agency thereof. 


\section{BEA Nuclear Safety Engineering}

\section{Conceptual Safety Design Report for the Remote-Handled Low-Level Waste Disposal Facility}

INL/EXT-09-17427

Revision 0

February 2010

Approved by:

INL Nuclear Safety Analysis

Michael Lehto

Date

INL Facility Safety Engineering, Manager

David Duncan

Date

INL Project Manager

Lisa Harvego

Date

INL Program Manager 
INL/EXT-09-17427

Revision 0

\begin{abstract}
A new onsite, remote-handled low-level waste (LLW) disposal facility has been identified as the highest ranked alternative for providing continued, uninterrupted remote-handled LLW disposal for remote-handled LLW from the Idaho National Laboratory and for spent nuclear fuel processing activities at the Naval Reactors Facility. Historically, this type of waste has been disposed of at the Radioactive Waste Management Complex. Disposal of remote-handled LLW in concrete disposal vaults at the Radioactive Waste Management Complex will continue until the facility is full or until it must be closed in preparation for final remediation of the Subsurface Disposal Area (approximately at the end of Fiscal Year 2017).

This conceptual safety design report supports the design of a proposed onsite remote-handled LLW disposal facility by providing an initial nuclear facility hazard categorization, by identifying potential hazards for processes associated with onsite handling and disposal of remote-handled LLW, by evaluating consequences of postulated accidents, and by discussing the need for safety features that will become part of the facility design.
\end{abstract}

NOTE:

This document summarizes the hazards for processes and the associated safety strategies to address the hazards associated with onsite handling and disposal of remote-handled lowlevel waste. A new on-site facility has been identified as an alternative for providing continued remote-handled low-level waste disposal capability in support of ongoing Department of Energy missions at the Idaho site. However, a decision has not been made by the Department of Energy to develop a new onsite disposal facility. The decision, following all required analyses and evaluation of the impacts of all viable alternatives, will be made in accordance with the National Environmental Policy Act of 1969. Use of words indicating requirements or specifying intention, such as "shall" or "will," are used for the convenience of discussion or to indicate requirements or activities that are conditioned on a decision to develop a new onsite disposal facility. Such usage should not be construed to mean that a final selection of an alternative has been made. 


\section{CONTENTS}

ABSTRACT iii

ACRONYMS vi

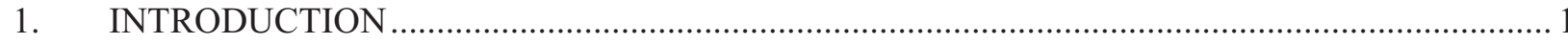

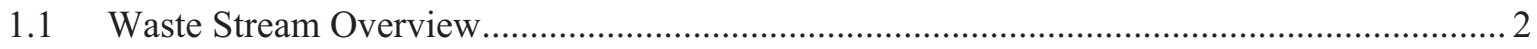

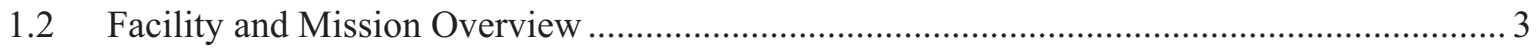

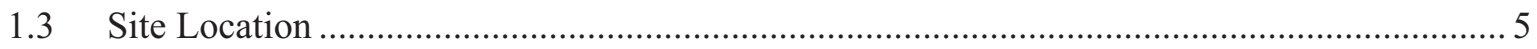

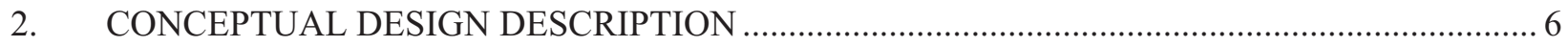

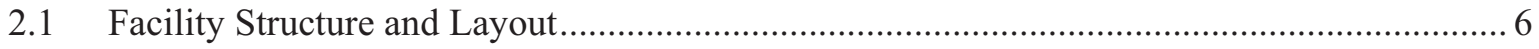

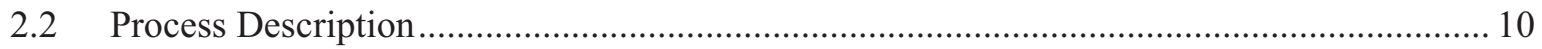

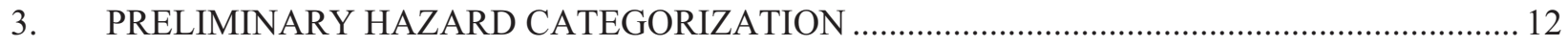

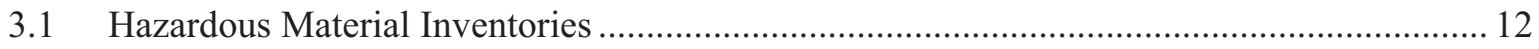

3.2 Comparison of Inventories to Threshold Quantities ..................................................... 15

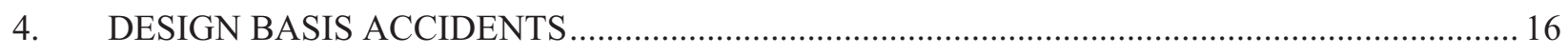

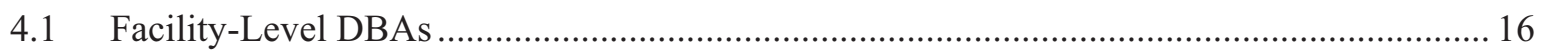

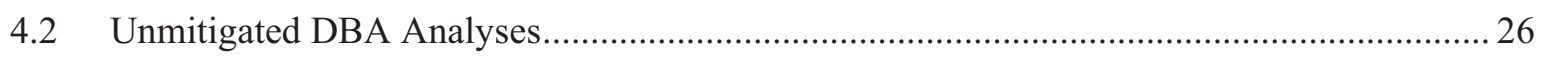

4.2.1 Container Drop Accident (cask or free-air transfer drop) …................................. 26

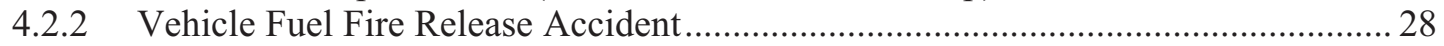

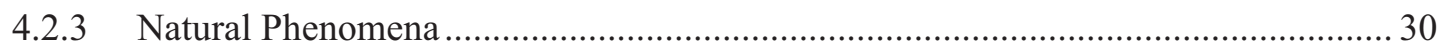

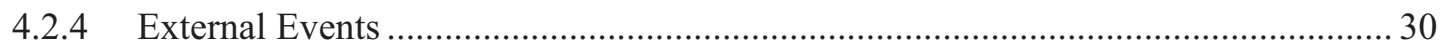

4.3 Preliminary Selection and Classification of Safety SSCs ................................................. 30

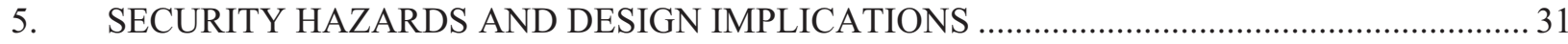

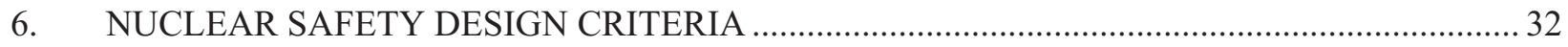

6.1 Approach for Compliance with Design Criteria …...................................................... 32

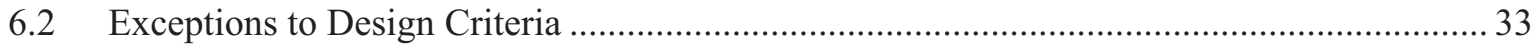

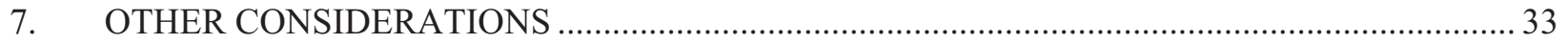

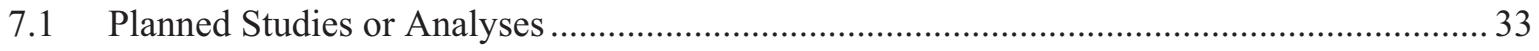


7.2 Safety-in-Design Risks and Opportunities ................................................................. 34

7.3 Lessons Learned From Previous Experience Involving Major Systems .............................. 35

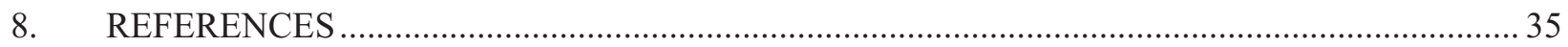

\section{FIGURES}

Figure 1. Projection of remote-handled LLW generation through Fiscal Year 2037. .............................. 4

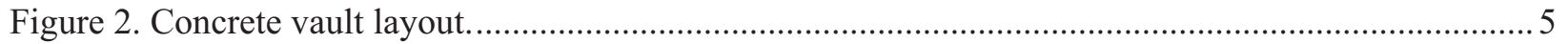

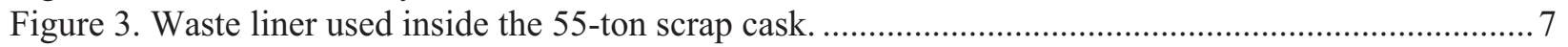

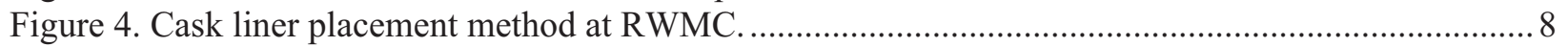

Figure 5. Proposed layout for the Remote-Handled LLW Disposal Facility........................................... 9

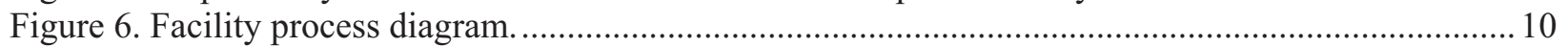

Figure 7. A 55-ton scrap cask used for transporting waste to the disposal facility................................ 11

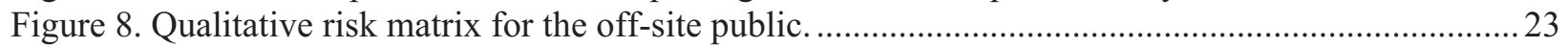

Figure 9. Qualitative risk matrix for collocated workers. ................................................................ 24

Figure 10. Qualitative risk matrix for facility workers. ................................................................. 25

\section{TABLES}

Table 1. Remote-handled low-level waste resins, and activated metals waste streams............................2

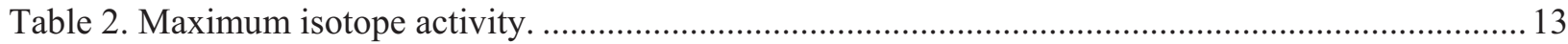

Table 3. Qualitative likelihood category for potential hazardous events.............................................. 17

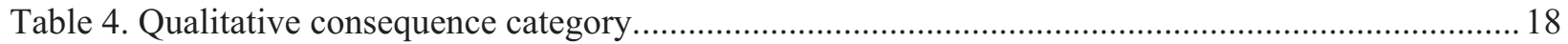

Table 5. Preliminary hazards identified for the proposed Remote-Handled LLW Disposal Facility......... 19 


\section{ACRONYMS}

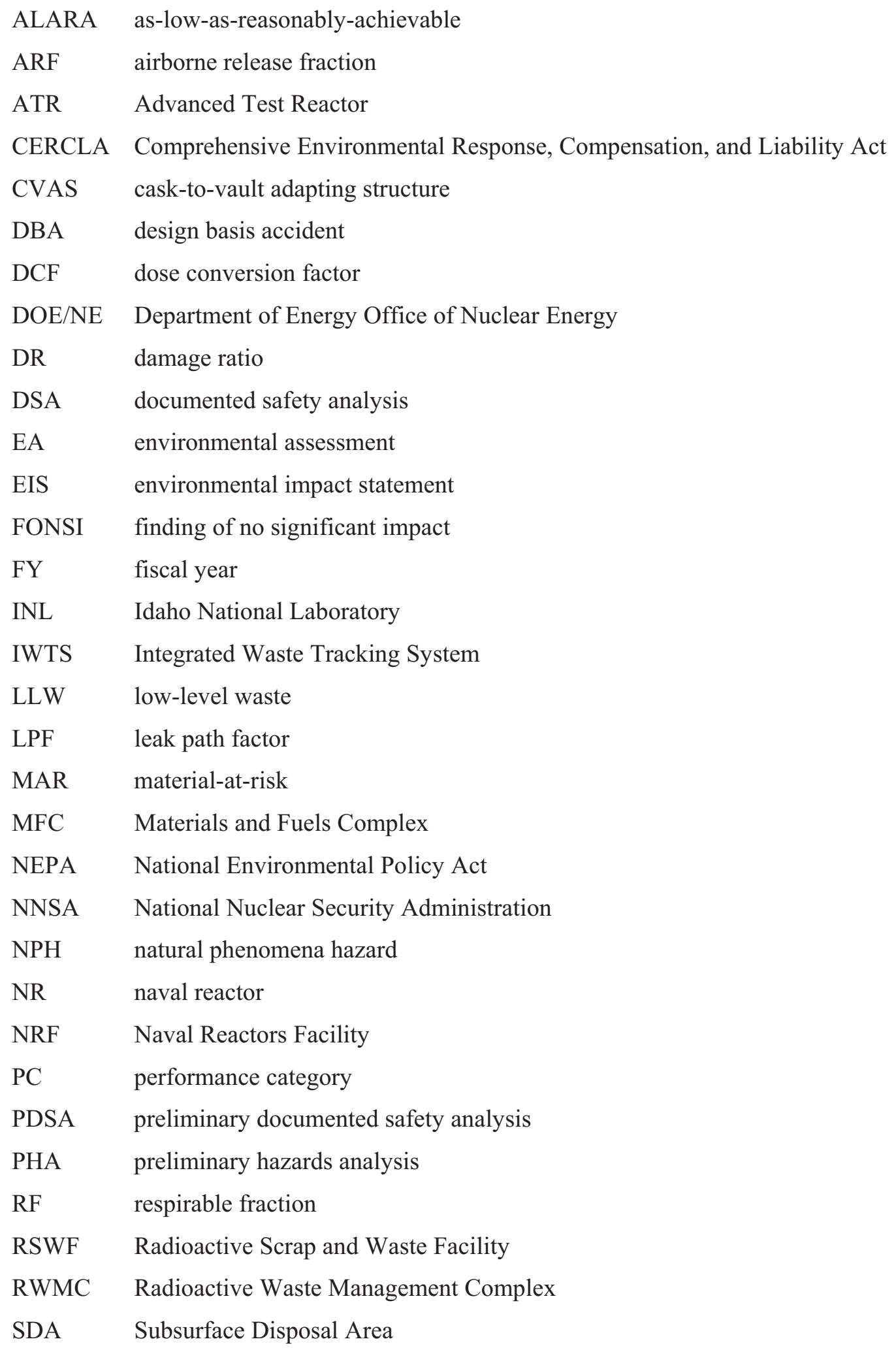


INL/EXT-09-17427

Revision 0

SSC structure, system, and component source term 


\section{Conceptual Safety Design Report for the Remote-Handled Low-Level Waste Disposal Facility \\ 1. INTRODUCTION}

The Idaho National Laboratory (INL) Site routinely generates contact-handled $(<200 \mathrm{mrem} / \mathrm{hr}$ on contact) and remote-handled ( $>200 \mathrm{mrem} / \mathrm{hr}$ on contact) LLW from facility operations and decontamination and decommissioning of inactive facilities. Historically, INL has disposed of its LLW in a disposal facility located at the Radioactive Waste Management Complex (RWMC). This facility includes disposal pits and concrete vaults. As part of ongoing cleanup activities at INL, closure of the RWMC is proceeding under the Comprehensive Environmental Response, Compensation, and Liability Act (CERCLA; 42 USC 9601 et seq. 1980). Disposal of LLW in the disposal pit ceased on September 30, 2008, and all contact-handled LLW and the portion of INL's remote-handled LLW that had been disposed of in the pit are being disposed offsite. Disposal of remote-handled LLW in concrete disposal vaults at RWMC will continue until the facility is full or until it is closed in preparation for final remediation of the Subsurface Disposal Area (SDA) (approximately at the end of fiscal year [FY] 2017).

On July 1, 2009, the Department of Energy (DOE) approved a mission need statement for the INL Remote-Handled LLW Disposal Project to develop replacement remote-handled LLW disposal capability in support of INL's nuclear energy mission and the Naval Nuclear Propulsion Program (DOE/ID-11364, "Mission Need Statement for the Idaho National Laboratory Remote-Handled Low-Level Waste Disposal Project"). The continuing nuclear mission of INL, associated ongoing and planned operations, and naval spent fuel activities at the Naval Reactors Facility (NRF) require continued capability to appropriately dispose of remote-handled LLW. Development of a new onsite disposal facility has been identified as the highest ranked alternative for providing continued, uninterrupted INL remote-handled LLW disposal capability (INL/EXT-09-17152, Remote-Handled Low-Level Waste Disposal Project Alternatives Analysis).

This conceptual safety design report (CSDR) has been prepared in accordance with DOE-STD-1189-2008, "Integration of Safety into the Design Process.” This CSDR:

- Documents and establishes a preliminary inventory of hazardous materials, including radioactive materials and chemicals

- Documents and establishes the preliminary hazard categorization of the proposed facility

- Identifies and analyzes primary facility hazards and facility design basis accidents (DBAs)

- Provides an initial determination, based on the preliminary hazard analysis (INL/EXT-07-12903, Preliminary Hazard Assessment for the Remote-handled Low-level Waste Disposal Facility), of safety-class and safety-significant structures, systems, and components (SSCs)

- Includes a preliminary assessment of the appropriate Seismic Design Category for the proposed facility

- Evaluates the security hazards that can impact the facility safety basis 
- Includes a commitment to the nuclear safety design criteria of DOE Order 420.1B, "Facility Safety."

\subsection{Waste Stream Overview}

The proposed Remote-Handled LLW Disposal Facility will be designed and constructed to support disposal of two remote-handled LLW waste streams generated at the Idaho Site: 1) remote-handled resins from the NRF and Advanced Test Reactor (ATR) Complex and 2) activated metals from NRF, ATR, and the Materials and Fuels Complex (MFC). Other remote-handled LLW waste streams have been generated at the INL in the past, may be generated in the future, or may be actively generated having an existing disposal pathway; the proposed facility, however, is being developed based on the identified resin and activated metal waste streams. Volumetric projections and characteristics of these waste streams provide an upper bound for remote-handled LLW that may be disposed at the proposed facility. A summary of these waste streams is provided in Table 1.

Table 1. Remote-handled low-level waste resins, and activated metals waste streams.

\begin{tabular}{|c|c|c|}
\hline $\begin{array}{l}\text { Waste } \\
\text { Stream }\end{array}$ & Generator & Description \\
\hline \multirow{2}{*}{ Resins } & $\begin{array}{c}\text { INL } \\
\text { ATR Complex }\end{array}$ & $\begin{array}{l}\text { ATR produces ion exchange resins from pool and reactor } \\
\text { operations. Until September } 30,2008 \text {, the waste was disposed of } \\
\text { in the RWMC pit. Since closure of the RWMC pit, the waste is } \\
\text { being disposed of offsite at NTS. }\end{array}$ \\
\hline & $\mathrm{NRF}$ & $\begin{array}{l}\text { NRF produces ion exchange resins from pool operations. } \\
\text { Currently, the waste is disposed of in the RWMC vaults in liners } \\
\text { transported using a 55-ton cask. }\end{array}$ \\
\hline \multirow{3}{*}{$\begin{array}{l}\text { Activated } \\
\text { Metals }\end{array}$} & $\begin{array}{c}\text { INL } \\
\text { ATR Complex }\end{array}$ & $\begin{array}{l}\text { ATR produces activated metals during reactor core change-out } \\
\text { operations approximately every eight years. These components } \\
\text { require an approximate eight-year decay time and are in storage } \\
\text { at the ATR Complex. Previous disposal has been at RWMC using } \\
\text { a cask that is no longer in use. The CNS 3-60B cask has been } \\
\text { identified as a potentially useful cask for this application. }\end{array}$ \\
\hline & $\mathrm{NRF}$ & $\begin{array}{l}\text { NRF produces activated metals during routine operations. } \\
\text { Currently, waste is disposed of in the RWMC vaults in } 55 \text {-ton } \\
\text { scrap cask liners. }\end{array}$ \\
\hline & INL MFC & $\begin{array}{l}\text { MFC will generate activated metals during waste segregation } \\
\text { operations for waste removed from the storage at the Radioactive } \\
\text { Scrap and Waste Facility. The CNS 3-60B cask has been } \\
\text { identified as a potentially useful cask for this application. }\end{array}$ \\
\hline
\end{tabular}

Ion-exchange resins from pool and reactor operations are generated at the ATR Complex (approximately $36 \mathrm{~m}^{3} / \mathrm{yr}$ ) and from pool operations at NRF (approximately $8 \mathrm{~m}^{3} / \mathrm{yr}$ ). ATR ion-exchange resin is generated approximately four to six times annually from reactor loop and reactor ion-exchange systems. The generation rate depends on reactor operations and also varies during the years when core internal change-outs are performed. The ion exchange resin waste stream has typical contact dose rates up to $15 \mathrm{R} / \mathrm{hr}$. 
ATR also produces about $3 \mathrm{~m}^{3}$ of activated metals during reactor core internal change-out operations, approximately every eight years. These components require decay time before they can be handled for disposal and are currently in temporary storage at the ATR Complex. NRF produces approximately $35 \mathrm{~m}^{3} / \mathrm{yr}$ of activated metals from the examination of test components and during routine operations removing irradiated non-fuel components from spent fuel modules. In addition, an estimated $60 \mathrm{~m}^{3}$ of activated metals are expected from new INL programs and from processing of remote-handled waste stored at the Radioactive Scrap and Waste Facility (RSWF) at MFC. The activated metals waste stream has typical contact dose rates up to $30,000 \mathrm{R} / \mathrm{hr}$.

\subsection{Facility and Mission Overview}

INL-generated radioactive waste has been disposed of at RWMC since 1952. RWMC disposal practices have evolved over time, including changes in the disposal facility, waste treatment, and containers. Current disposal operations within the SDA are limited to subsurface burial of INL-generated LLW; disposal of waste from offsite generators was discontinued in the early 1990s. Waste emplaced in the SDA is classified as either remote- or contact-handled LLW, depending on radiation levels.

Providing continued disposal capability for remote-handled LLW supports the Office of Nuclear Energy, Science, and Technology's mission "to lead the DOE investment in the development and exploration of advanced nuclear science and technology." Without established, viable remote-handled LLW disposal capability, ongoing and future Office of Nuclear Energy, Science, and Technology programs at INL would be adversely impacted as remote-handled LLW disposal options would need to be considered on a program-by-program basis, resulting in increased costs and schedule. The lack of remotehandled LLW disposal capability also may impede DOE's ability to initiate new programs at the INL.

Remote-handled LLW disposal capability is also critical to meeting the National Nuclear Security Administration's (NNSA's) mission to "provide the United States Navy with safe, militarily effective nuclear propulsion plants and to ensure the safe and reliable operation of those plants." All spent nuclear fuel from the Navy's nuclear-powered fleet is sent to NRF for examination, processing, dry storage, and eventual shipment to a permanent geologic repository. A reliable disposal path for remote-handled LLW generated during spent nuclear fuel handling and packaging operations is essential to NRF's continued receipt and processing of Navy spent fuel and to the Naval Nuclear Propulsion Program as well as national security. The mission need statement for the INL Remote-Handled LLW Disposal Project, created as a result of evaluating INL-generated LLW disposal options, is as follows:

The INL will develop replacement remote-handled low-level waste disposal capability ... to support cost-effective, efficient operations in support of INL's nuclear energy mission and the Naval Nuclear Propulsion Program. Such disposal capability is required to enhance ongoing Departmental and National mission-based research, defense, and energy programs.

From current waste generation projections presented in Figure 1, INL must have the capability to dispose of approximately $88 \mathrm{~m}^{3} / \mathrm{yr}$ of remote-handled LLW with typical radiation exposure levels up to 30,000 R/hr, commencing by the end of FY 2017 when RWMC stops accepting remote-handled LLW at the SDA concrete disposal vaults. 


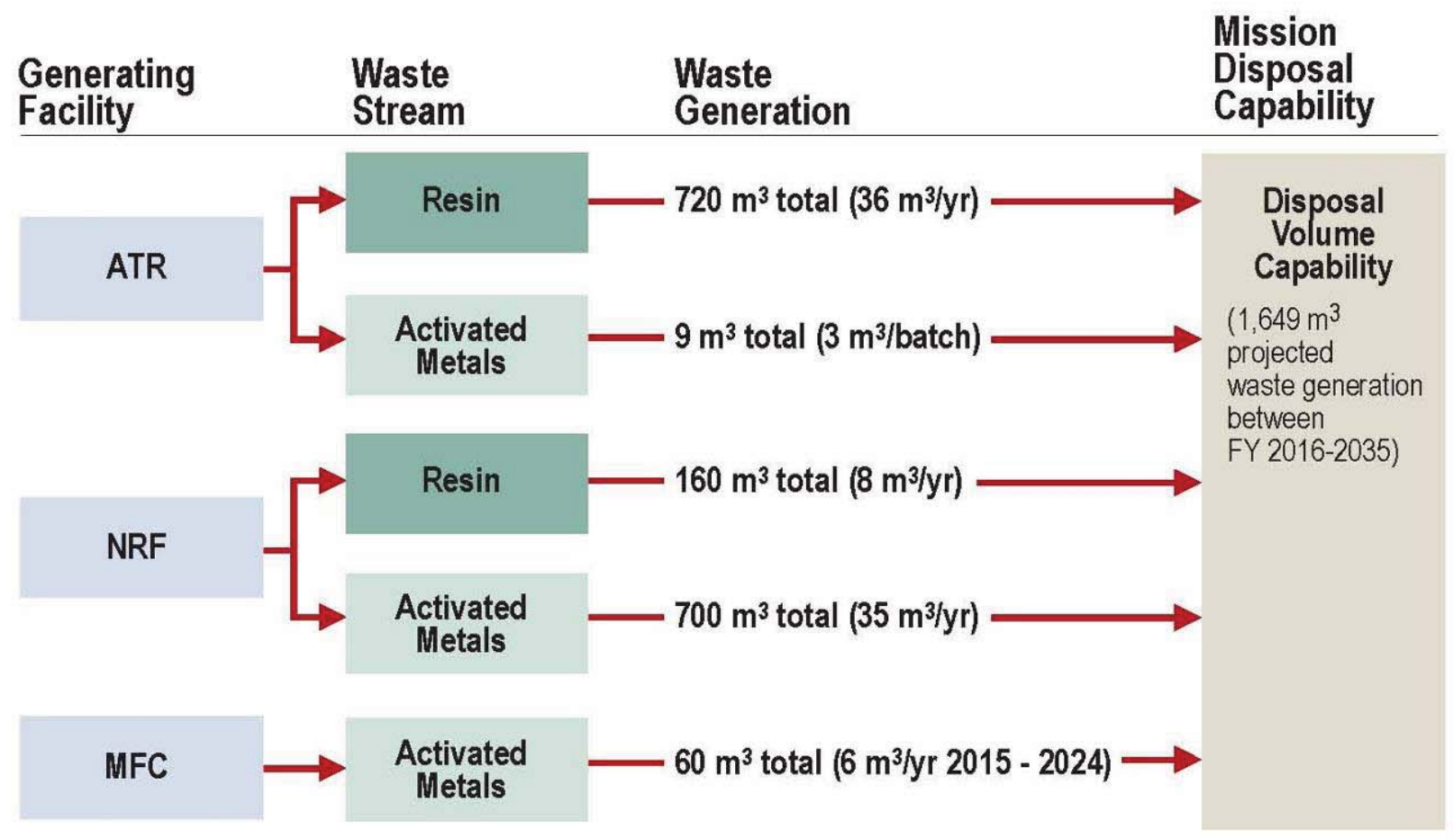

Figure 1. Projection of remote-handled LLW generation through Fiscal Year 2037.

The proposed Remote-Handled LLW Disposal Facility will provide concrete disposal vaults needed to dispose of the estimated quantities of activated metals and ion-exchange resins classified as remote-handled LLW. It is anticipated that the facility will utilize a concrete vault system that will consist of precast concrete cylinders stacked on end and buried in an array, such as presently used at RWMC. Each stacked cylinder will be placed on a concrete base and will have a separate removable concrete plug placed on top of the cylinder to serve as a radiation shield and a water barrier (see Figure 2). Specifically, the proposed Remote-Handled LLW Disposal Facility will be designed to do the following:

- $\quad$ Provide a concrete vault disposal system that can accommodate cask liners that are currently being used for waste disposal of remote-handled LLW generated at NRF

- $\quad$ Provide a concrete vault disposal system that can accommodate cask liners that are anticipated to be used for disposal of activated metals generated at ATR and from new missions, including processing of waste currently in storage at RSWF

- $\quad$ Provide a concrete vault disposal system that can accommodate cask liners that are currently being used for disposal of remote-handled LLW ATR resins

- Accommodate cask liner placement methods currently in use at RWMC and continue to utilize the existing remote-handled loading equipment and proven procedures for the NRF shipping cask

- $\quad$ Provide support equipment needed to unload cask liners that are anticipated to be used by ATR, RSWF, and other future mission activities

- $\quad$ Provide road access that can accommodate anticipated loads from cask transport vehicles 
- $\quad$ Place cask liners into vaults while providing the appropriate level of shielding and worker protection

- $\quad$ Provide a vault/plug assembly to provide shielding, minimize entry of water into the vaults, and allow drainage of any moisture/condensate that accumulates inside the vaults

- $\quad$ Allow access to individual vaults without disturbing adjacent vaults

- $\quad$ Provide crane access areas to support the placement of waste materials into the vaults, as needed, that will support the combined weight of a loaded crane during placement (crane, cask, cask-tovault adapter components, shielding/sealing plug, and cask liners)

- $\quad$ Provide shielding sufficient to reduce radiation levels on top of the vaults to the levels specified in DOE Order 5400.5, "Radiation Protection of the Public and the Environment," when the plugs are in place.

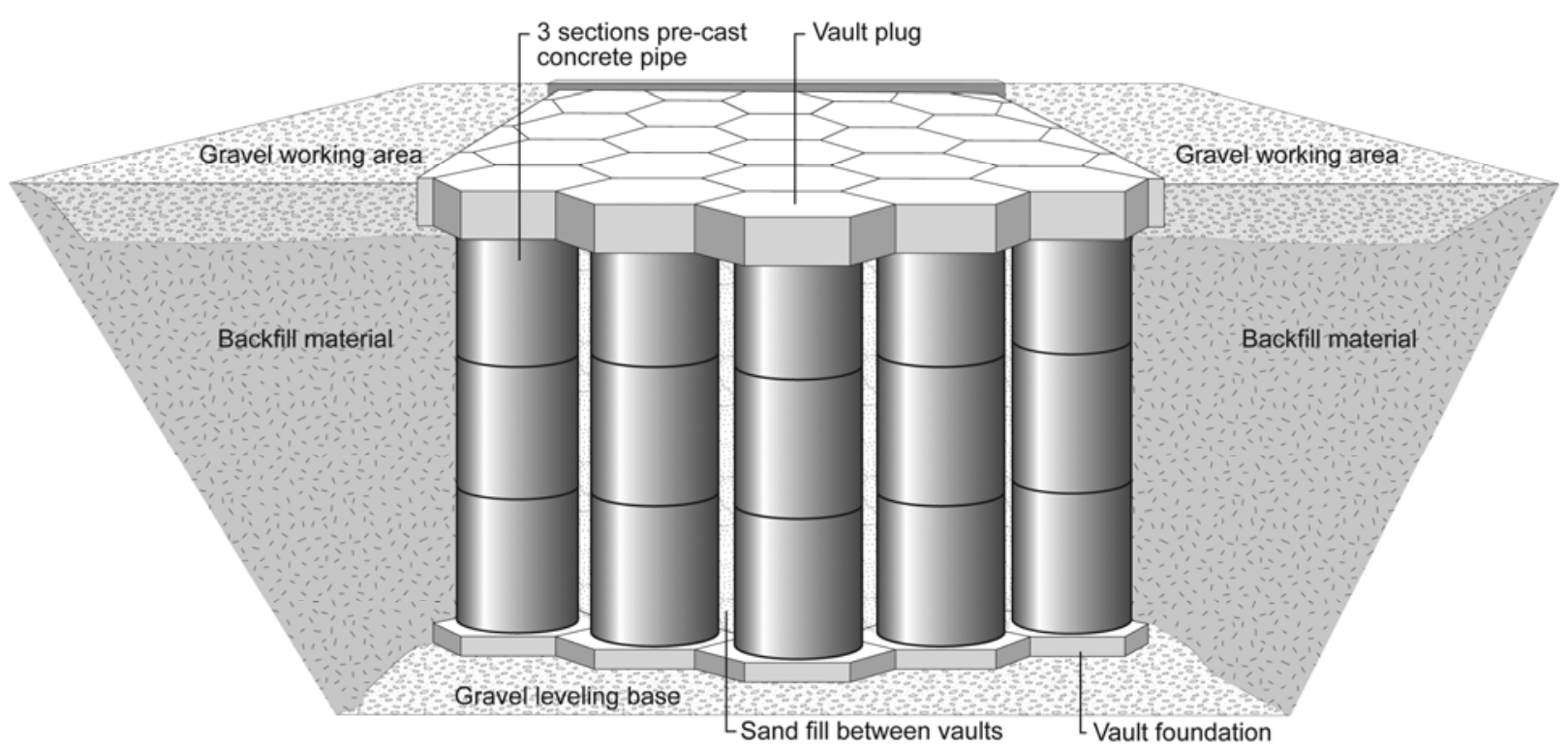

Figure 2. Concrete vault layout.

\subsection{Site Location}

At this stage of project development, it is assumed that the facility will be a stand-alone facility that does not use the services of any existing INL facilities. The facility is proposed to be sited within INL boundaries, north of U.S. Highway 20, and operated by the INL site operating contractor. Perimeter fencing will be constructed to provide protection from human and animal intrusions and to allow for proper access control. Specific interfaces between the proposed facility and existing INL facilities will be defined once a location is selected in accordance with the National Environmental Policy Act (NEPA) process.

An overall facility area for siting purposes will be based on the required site-specific components and is estimated to be between 4 to 6 acres (1.6 to 2.4 ha). The total number of vaults that are needed may change depending on the ability to support a vault depth capable of accepting three liners per vault. 
A siting study is being conducted to support the NEPA process that will consider possible locations within the INL that are best suited for locating the proposed facility. The study will consider five key elements: (1) regulations, (2) key assumptions, (3) conceptual design, (4) facility performance, and (5) previous INL siting studies; the study will use a five-step process to identify, screen, evaluate, score, and rank multiple sites located across the INL.

Once the final location is decided, the safety basis documents will be updated to reflect the specific siting location and any site-specific characteristics that could impact nuclear safety considerations for the proposed facility.

\section{CONCEPTUAL DESIGN DESCRIPTION}

\subsection{Facility Structure and Layout}

Initial construction of the proposed remote-handled LLW disposal facility will provide up to 250 new disposal vaults that are similar to the existing RWMC vault design. The vaults will be constructed of precast concrete cylinders (i.e., pipe sections) stacked on end and placed within an array as shown in Figure 2. This configuration provides the ability to dispose of the desired quantity of waste within the smallest footprint possible.

The following are major components of the proposed facility:

- Vaults - The pre-cast concrete vault sections will be aligned vertically to allow multiple remotehandled LLW liner stacking in an upright orientation. Vaults used to dispose of NRF waste will be designed to interface with the existing cask-to-vault adapting structure (CVAS) and the 55-ton scrap cask. Remaining vaults will be designed to interface with the applicable cask and associated transfer system. All appropriate handling equipment consistent with the current configuration and practices will be utilized.

- Vault plugs - A removable concrete plug will be placed on top of each vault. The plug will serve as a radiation shield for placed waste and also will act as a water barrier to prevent surface water intrusion into the concrete vaults.

- Crane-The Manitowac 3,900 W, Series 2 crane that is currently in use at RWMC will be disassembled, refurbished, and transported to the new disposal facility. This crane is a mobile two track crane with a total weight of $262,225 \mathrm{lb}(118,943 \mathrm{~kg})$ and a lifting capacity of approximately 140 tons $(127,000 \mathrm{~kg})$. If it is determined that the existing crane will not be available, a new crane with similar lifting capacity will need to be procured for the facility.

- Waste liner (container) - Remote-handled LLW will be packaged into steel liners (i.e., waste containers) at the generating facilities. One liner at a time is shipped within a shielded cask from the generating facility to the disposal facility. Upon cask arrival at the appropriate vault array location, the liner will be transferred directly from the bottom unloading cask into the concrete vault. These liners function as a contamination barrier (ref. Figure 3 ). 
INL/EXT-09-17427

Revision 0

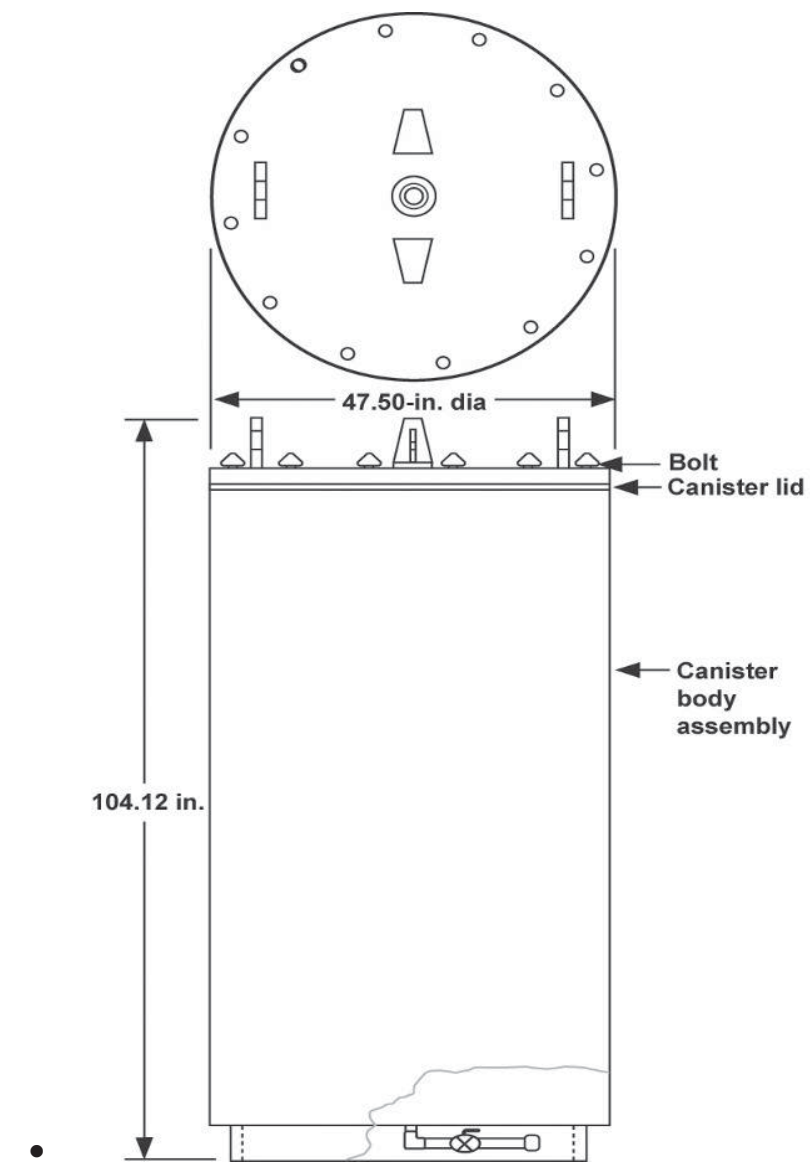

Figure 3. Waste liner used inside the 55-ton scrap cask.

- Liner hoist - The waste liner hoisting system is one of the primary mechanical systems in the facility. The liner hoisting system is used to lower waste liners for placement into the vaults. Development of the liner hoists is the responsibility of the waste generating facility.

- CVAS - The CVAS currently located at RWMC will be transferred to the new disposal facility. This system is currently owned by NRF. All supporting equipment and components, such as the lifting rigging and control trailer, also will be made available for use. Similar CVAS will be required to accommodate the configuration of other INL generated remote-handled LLW.

- Staging and storage area-Staging and storage pads will be provided within the facility for operating equipment. These pads will be constructed using pit run gravel with a crushed gravel top surface. Areas will be provided for storage of the crane; the CVAS components, including the working platform; the bearing pad; the shield plugs; and the electrical control trailer.

- Administrative and other supporting infrastructure - Additional support and administrative structures and services are included in the conceptual design, which include the following:

- Administration building

- Office space

- Records storage

- Equipment storage 
- Electrical distribution

- Maintenance enclosure

- Equipment maintenance area

- Temporary cask holding area

- Equipment decontamination area

- Equipment storage area

- Access roads

- Vehicle access within facility and around vaults

- Facility road providing access to/from major road

- Electrical power infrastructure

- Perimeter fencing and lighting

- Video monitoring

- Firewater.

Remote-handled LLW destined for disposal will be packaged into shielded casks with waste liners. The liners will normally consist of cylindrical containers designed specifically for the cask systems used. It is assumed that remote-handled LLW will be transported from NRF to the new disposal facility in a 55-ton scrap cask and, for purposes of this conceptual safety design report, the existing RWMC method of cask liner placement will be used (see Figure 4). Given the size constraints of the casks, only one waste liner will be transported in a cask at any one time. The operational system associated with the cask and transfer system used by other INL generators will be determined once specific liner designs and cask systems are identified; however, operations will be substantially equivalent to those required for handling the NRF 55-ton scrap cask. At this stage of the design, radiation surveys conducted as part of normal operations are the only safety and health monitoring or surveillance identified to be performed.

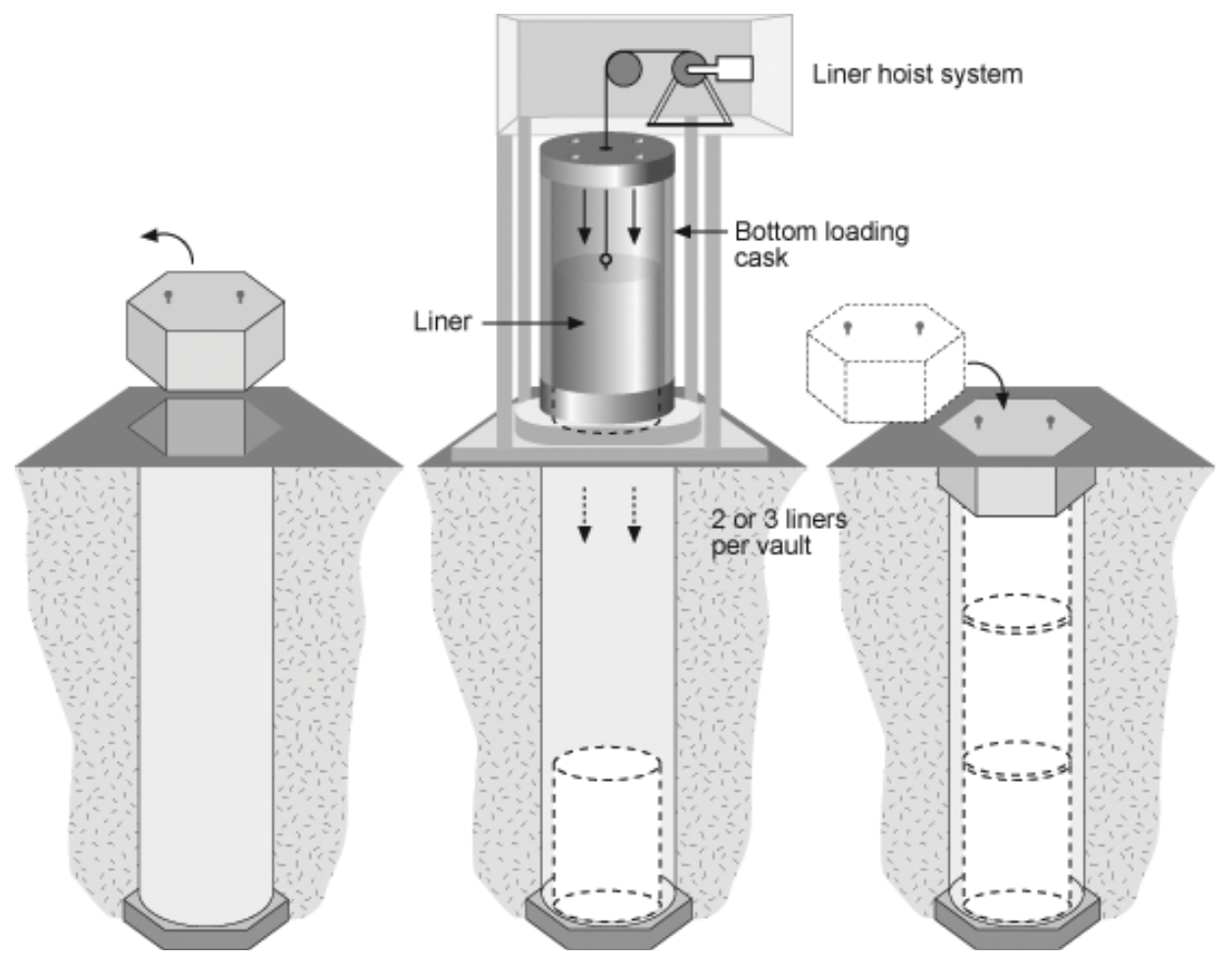

Figure 4. Cask liner placement method at RWMC. 
The proposed facility will be laid out in a manner to allow trucks entering the disposal facility to have straight access to the unloading area next to the disposal vaults. The crane and other miscellaneous equipment required for completion of the cask to vault transfer operation will be staged before arrival of the waste containers. Figure 5 illustrates the facility configuration and includes a photo that shows the equipment currently staged for operation at RWMC. The new facility will use these same methods and will set up the necessary equipment in a similar configuration.

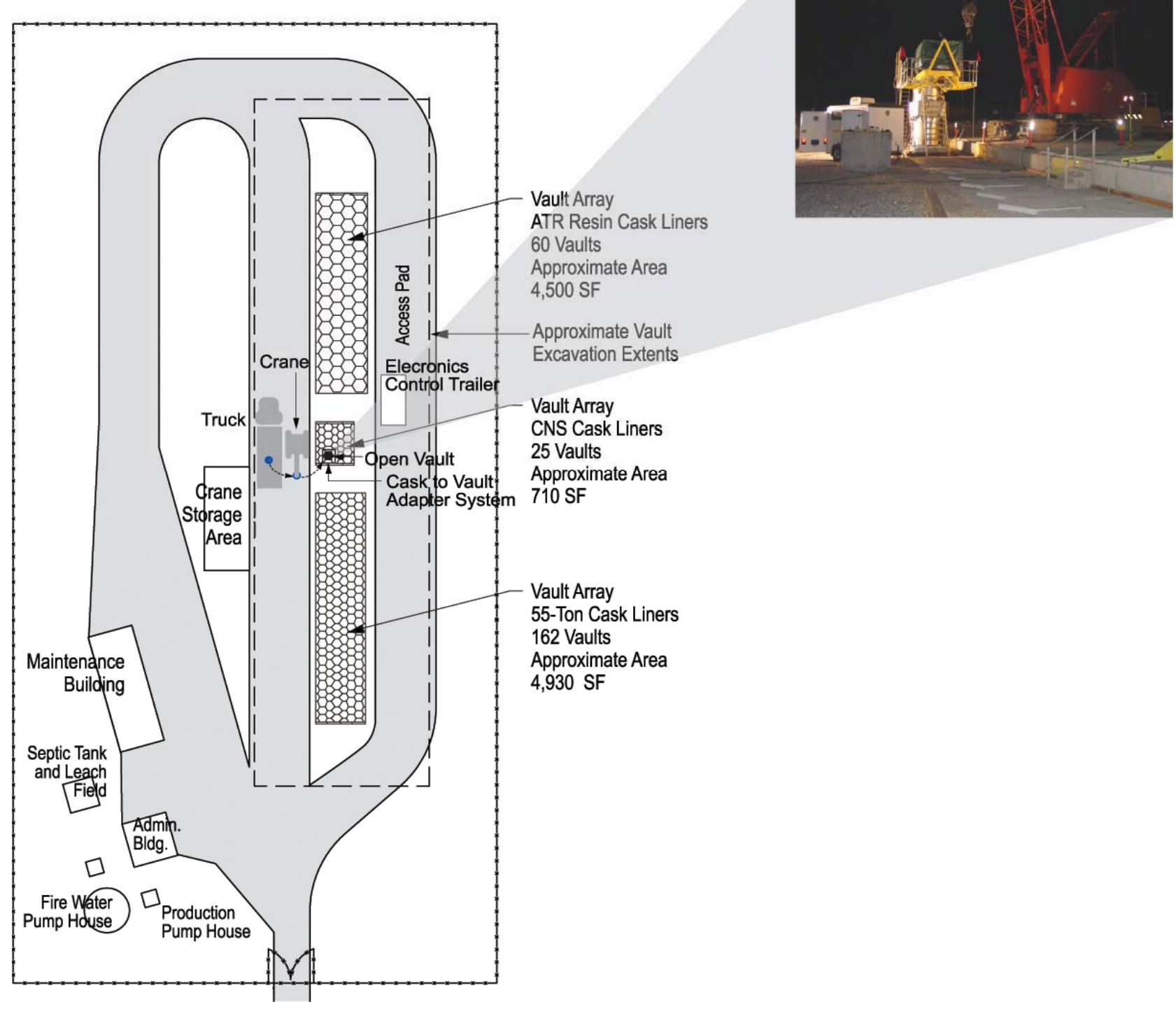

Figure 5. Proposed layout for the Remote-Handled LLW Disposal Facility.

The total number of vaults that will be constructed will depend on the depth of surficial sediment at the specific site that is selected for the facility. The general layout in the conceptual design shows the areal extent of the vaults, as determined using a vault depth that can accommodate disposal of two liners per vault. In this configuration, a minimum of 160 vaults will be needed for NRF waste, 60 vaults for ATR resins, and 23 vaults for activated metals from ATR processing of co-mingled, remote-handled LLW currently stored in RSWF and new INL programs. If the selected site has sufficient surficial 
sediment to accommodate three liners per vault, the total number of required vaults would be reduced by one third.

\subsection{Process Description}

This section describes the overall process used for disposal of remote-handled LLW at INL. Figure 6 shows the general process that is currently being used for remote-handled LLW disposal at RWMC. It is assumed that all future waste received from each of the INL generating facilities will be received and disposed of using this same, or similar, sequence of activities. This process is the basis for development of the technical and functional requirements and hazard and accident analysis for the new disposal facility.

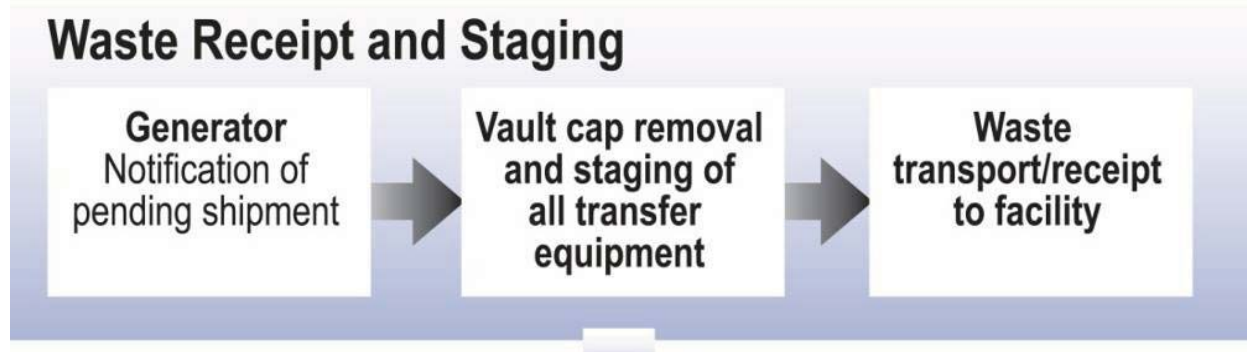

\section{Disposal}

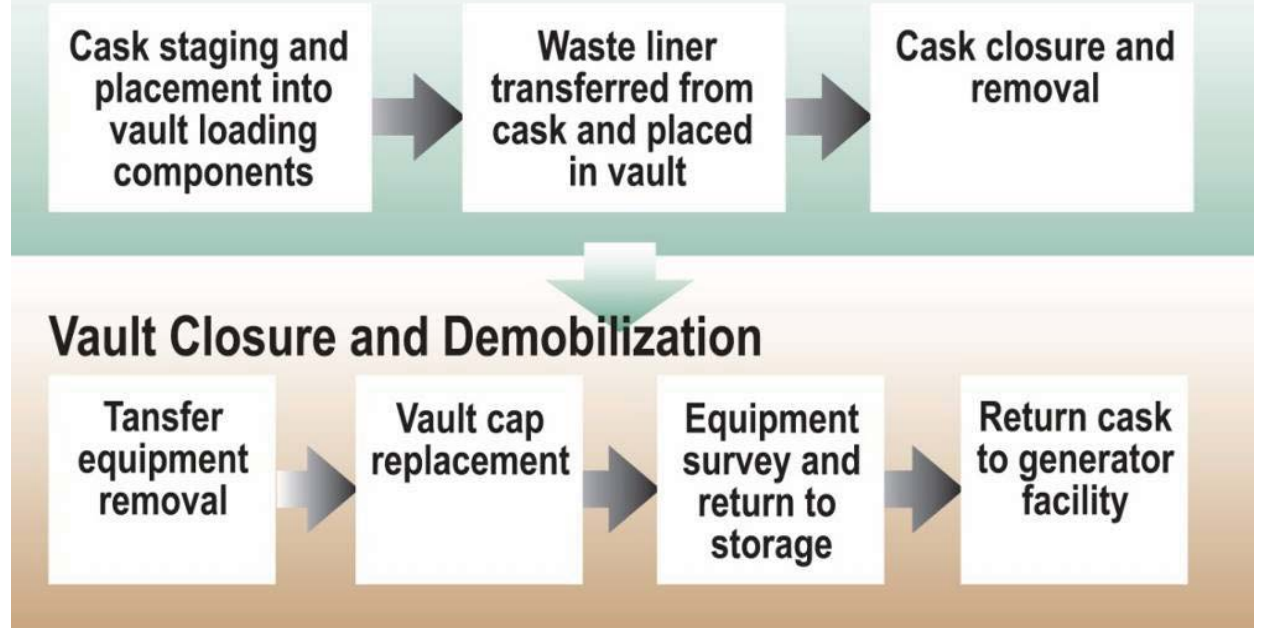

Figure 6. Facility process diagram.

The current NRF waste liner placement process consists of the following steps:

1. Once waste is transported to the site (utilizing the NRF 55-ton scrap cask), a crane is used to remove the top plug on the vault and to position the CVAS on top of the open vault.

2. The 55-ton scrap cask (ref. Figure 7) is removed from the transporter and placed on the CVAS using the crane.

3. Using a remote-operated hoisting system, the cask liner is unloaded from the bottom of the cask and lowered into the disposal vault. 
4. The cask is then closed and the hoisting system with the associated equipment is removed from the top of the vault.

5. The vault is then closed.

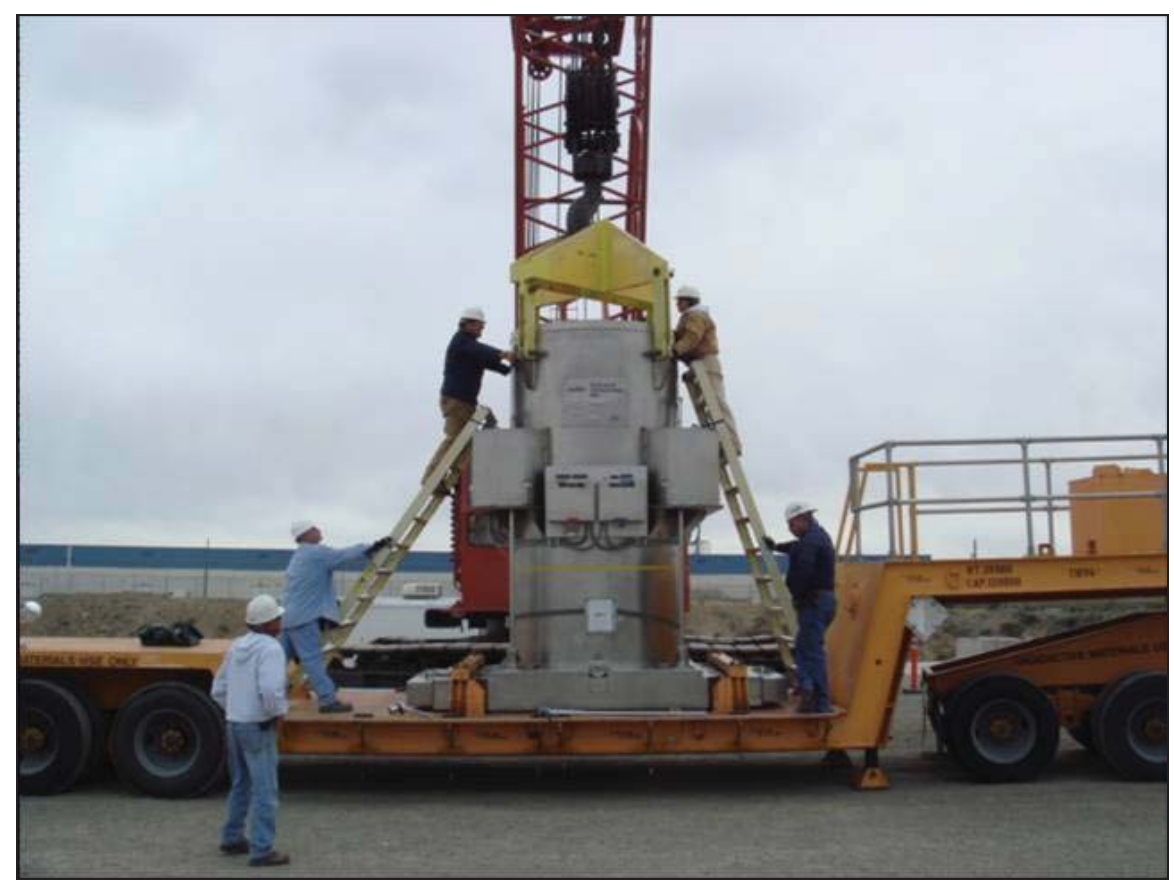

Figure 7. A 55-ton scrap cask used for transporting waste to the disposal facility.

The specific operational systems and placement procedures that will be used in association with the other cask systems used for disposal of the remote-handled LLW at the proposed facility will be determined once the generating facilities identify their specific liner configurations. It is assumed that the following general operational sequence would be used for placement of the waste liners into the associated disposal vaults:

1. Once waste is transported to the site, a crane will be used to remove the top plug on the vault and prepare the vault opening for liner placement.

2. Using the crane, the liner will be removed from the cask (using the associated liner handling equipment) and positioned over the disposal vault.

3. The liner will be lowered into the disposal vault.

4. The transfer equipment will be removed and the vault plug replaced.

It is anticipated that other waste packages (i.e., cask liners) will be developed and used for ATR waste and for activated metals planned to be generated from new missions and from processing of remote-handled scrap and waste currently stored at MFC's RSWF. 


\section{PRELIMINARY HAZARD CATEGORIZATION}

With respect to nuclear safety, a hazard is defined as a source of danger (i.e., material, energy source, or operation) with the potential to cause illness, injury, or death to personnel or damage to an operation or to the environment (without regard for the likelihood or credibility of accident scenarios or consequence mitigation). To identify potential facility hazards, the following were examined:

- The quantity, form, and location of radioactive and hazardous materials that are potentially releasable from the Remote-Handled LLW Disposal Facility.

- Potential energy sources and initiating events that could directly result in injury to workers or lead to release of radioactive or hazardous materials.

\subsection{Hazardous Material Inventories}

Remote-handled LLW is considered as any waste container with a contact dose equivalent rate (including neutron and beta radiation) $>200 \mathrm{mrem} / \mathrm{hr}$ at contact. If internally or externally shielded, the $>200 \mathrm{mrem} / \mathrm{hr}$ limit applies to the expected dose equivalent rate without shielding. Should shielded containers be designed for placement in the proposed Remote-Handled LLW Disposal Facility, such containers will not have any Resource Conservation and Recovery Act regulated metals used as shielding.

External dose rate dictates shielding requirements for the facility vault plugs and for packages transported to and from the facility to maintain worker exposure as-low-as-reasonably-achievable (ALARA) in accordance with the INL Radiological Control Program.

Consideration should be given to protection of the worker during open air transfers, which are planned for the facility. These transfers from the top load/unload transportation casks to the disposal vaults are expected for moving resin and activated metals in casks that do not unload from the bottom. This operation has successfully been performed utilizing remote operations where workers maintain a safe distance from the liner and vault while the move is performed. Protection to the worker is provided by the use of distance and temporary shielding as administrative controls found in the radiation protection program. It is expected that through experience and training, worker proficiency will reduce the time required to make the open air transfers.

Hazardous material inventories for construction and operation of the proposed Remote-Handled LLW Disposal Facility are very low in comparison to other INL operations and commensurate with existing RWMC remote-handled LLW operations. No chemicals found in the Occupational Safety and Health Act substance specific standards have been identified that would create a potential for exposure triggering medical surveillance during construction or operation. Additionally, no highly hazardous chemicals listed in 29 CFR 1910.119, "Process Safety Management of Highly Hazardous Chemicals," (Appendix A, List of Highly Hazardous Chemicals, or Toxics and Reactives) will be generated, used, or disposed of at this facility.

Table 2 below is a list showing potential isotopes found in Integrated Waste Tracking System (IWTS) waste stream 2534: "NRF 55-ton scrap cask insert with remote handled low level waste." This waste stream provides a conservative upper bound for all remote-handled LLW waste streams identified for disposal at the proposed facility. The data in this table is given as the upper levels anticipated $\left(\right.$ per $\mathrm{m}^{3}$ ) in this waste stream. It is understood that this represents the maximum of a range of each isotope and is not indicative of every shipment made to the remote-handled LLW facility. The container inventory is compared to threshold quantities (TQ) for Hazard Category 3 (HC-3) and Hazard Category 2 (HC-2) facilities as discussed in DOE-STD-1027-92. Fractions of the respective TQs for HC-3 and HC-2 are 
shown for each isotope as applicable, and a sum of fractions is shown at the bottom of the table for the maximum allowable inventory per cubic meter of waste.

Table 2. Maximum isotope activity.

\begin{tabular}{|c|c|c|c|c|c|}
\hline Isotope & $\begin{array}{l}\text { Maximum activity } \\
\text { concentration } \mathrm{Ci} / \mathrm{m}^{3}\end{array}$ & $\begin{array}{l}\text { HC-3 TQ } \\
\text { (Ci) }\end{array}$ & $\begin{array}{l}\text { HC-2 TQ } \\
\text { (Ci) }\end{array}$ & Fraction HC-3 & Fraction HC-2 \\
\hline Ag-108m & $2.455 \mathrm{E}-03$ & $2.0 \mathrm{E}+02$ & & $1.23 \mathrm{E}-05$ & \\
\hline $\mathrm{Ag}-110 \mathrm{~m}$ & $1.932 \mathrm{E}-04$ & $2.6 \mathrm{E}+02$ & $5.3 \mathrm{E}+05$ & 7.43E-07 & $3.65 \mathrm{E}-10$ \\
\hline Ar-39 & $2.198 \mathrm{E}-03$ & $4.0 \mathrm{E}+04$ & & $5.50 \mathrm{E}-08$ & \\
\hline Ba-133 & $3.654 \mathrm{E}-06$ & $1.1 \mathrm{E}+03$ & $4.0 \mathrm{E}+06$ & $3.32 \mathrm{E}-09$ & $9.14 \mathrm{E}-13$ \\
\hline Be-10 & $1.065 \mathrm{E}-05$ & $1.04 \mathrm{E}+02$ & & $1.02 \mathrm{E}-07$ & \\
\hline Bi-212 & $4.275 \mathrm{E}-06$ & $2.0 \mathrm{E}+03$ & & $2.14 \mathrm{E}-09$ & \\
\hline $\mathrm{C}-14$ & $5.000 \mathrm{E}+00$ & $4.2 \mathrm{E}+02$ & $1.4 \mathrm{E}+06$ & $1.19 \mathrm{E}-02$ & $3.57 \mathrm{E}-06$ \\
\hline $\mathrm{Ca}-45$ & $2.838 \mathrm{E}-03$ & $1.1 \mathrm{E}+03$ & $4.7 \mathrm{E}+06$ & $2.58 \mathrm{E}-06$ & $6.04 \mathrm{E}-10$ \\
\hline Cd-109 & $5.666 \mathrm{E}-05$ & $1.8 \mathrm{E}+02$ & $2.9 \mathrm{E}+05$ & $3.15 \mathrm{E}-07$ & $1.95 \mathrm{E}-10$ \\
\hline Cd-113m & $1.151 \mathrm{E}-05$ & $1.18 \mathrm{E}+01$ & & $9.75 \mathrm{E}-07$ & \\
\hline Cd-115m & $8.479 \mathrm{E}-07$ & $2.2 \mathrm{E}+02$ & & $3.85 \mathrm{E}-09$ & \\
\hline Ce-141 & $6.132 \mathrm{E}-05$ & $1.0 \mathrm{E}+03$ & $3.3 \mathrm{E}+06$ & $6.13 \mathrm{E}-08$ & $1.86 \mathrm{E}-11$ \\
\hline Ce-144 & $5.592 \mathrm{E}-02$ & $1.0 \mathrm{E}+02$ & $8.2 \mathrm{E}+04$ & $5.59 \mathrm{E}-04$ & $6.82 \mathrm{E}-07$ \\
\hline $\mathrm{Cl}-36$ & $2.500 \mathrm{E}-02$ & $3.4 \mathrm{E}+02$ & $1.4 \mathrm{E}+03$ & $7.35 \mathrm{E}-05$ & $1.79 \mathrm{E}-05$ \\
\hline Co-57 & $3.865 \mathrm{E}-02$ & $6.0 \mathrm{E}+03$ & & $6.44 \mathrm{E}-06$ & \\
\hline Co-58 & $4.014 \mathrm{E}+01$ & $9.0 \mathrm{E}+02$ & & 4.46E-02 & \\
\hline Co-60 & $1.000 \mathrm{E}+04$ & $2.8 \mathrm{E}+02$ & $1.9 \mathrm{E}+05$ & $3.57 \mathrm{E}+01$ & $5.26 \mathrm{E}-02$ \\
\hline $\mathrm{Cr}-51$ & $1.670 \mathrm{E}+00$ & $2.2 \mathrm{E}+04$ & $1.0 \mathrm{E}+08$ & 7.59E-05 & $1.67 \mathrm{E}-08$ \\
\hline Cs-134 & $1.807 \mathrm{E}-01$ & $4.2 \mathrm{E}+01$ & $6.0 \mathrm{E}+04$ & 4.30E-03 & $3.01 \mathrm{E}-06$ \\
\hline Cs-137 & $3.000 \mathrm{E}-01$ & $6.0 \mathrm{E}+01$ & $8.9 \mathrm{E}+04$ & $5.00 \mathrm{E}-03$ & $3.37 \mathrm{E}-06$ \\
\hline $\mathrm{Eu}-152$ & $2.050 \mathrm{E}-01$ & $2.0 \mathrm{E}+02$ & $1.3 \mathrm{E}+05$ & $1.03 \mathrm{E}-03$ & $1.58 \mathrm{E}-06$ \\
\hline Eu-154 & $9.909 \mathrm{E}+00$ & $2.0 \mathrm{E}+02$ & $1.1 \mathrm{E}+05$ & $4.95 \mathrm{E}-02$ & $9.01 \mathrm{E}-05$ \\
\hline $\mathrm{Eu}-155$ & $3.458 \mathrm{E}+00$ & $9.4 \mathrm{E}+02$ & $7.3 \mathrm{E}+05$ & $3.68 \mathrm{E}-03$ & 4.74E-06 \\
\hline $\mathrm{Fe}-55$ & $3.850 \mathrm{E}+03$ & $5.4 \mathrm{E}+03$ & $1.1 \mathrm{E}+07$ & 7.13E-01 & $3.50 \mathrm{E}-04$ \\
\hline $\mathrm{Fe}-59$ & $2.313 \mathrm{E}-01$ & $6.0 \mathrm{E}+02$ & $1.8 \mathrm{E}+06$ & $3.86 \mathrm{E}-04$ & $1.29 \mathrm{E}-07$ \\
\hline Gd-153 & $4.943 \mathrm{E}-03$ & $1.0 \mathrm{E}+03$ & $1.4 \mathrm{E}+06$ & 4.94E-06 & $3.53 \mathrm{E}-09$ \\
\hline $\mathrm{H}-3$ & $5.000 \mathrm{E}+00$ & $1.6 \mathrm{E}+04$ & $3.0 \mathrm{E}+05$ & $3.13 \mathrm{E}-04$ & $1.67 \mathrm{E}-05$ \\
\hline Hf-175 & $5.916 \mathrm{E}-02$ & $2.0 \mathrm{E}+03$ & & $2.96 \mathrm{E}-05$ & \\
\hline Hf-181 & $9.591 \mathrm{E}-02$ & $7.6 \mathrm{E}+02$ & $2.2 \mathrm{E}+06$ & $1.26 \mathrm{E}-04$ & $4.36 \mathrm{E}-08$ \\
\hline $\mathrm{Hg}-203$ & $1.586 \mathrm{E}-06$ & $3.6 \mathrm{E}+02$ & $4.3 \mathrm{E}+05$ & 4.41E-09 & $3.69 \mathrm{E}-12$ \\
\hline I-129 & $7.000 \mathrm{E}-07$ & $6.0 \mathrm{E}-02$ & & $1.17 \mathrm{E}-05$ & \\
\hline In-113m & $4.327 \mathrm{E}+00$ & $3.0 \mathrm{E}+04$ & & $1.44 \mathrm{E}-04$ & \\
\hline In-114m & $1.129 \mathrm{E}-02$ & $2.2 \mathrm{E}+02$ & $3.7 \mathrm{E}+05$ & $5.13 \mathrm{E}-05$ & $3.05 \mathrm{E}-08$ \\
\hline Ir-192 & $2.480 \mathrm{E}-02$ & $9.4 \mathrm{E}+02$ & $1.2 \mathrm{E}+06$ & $2.64 \mathrm{E}-05$ & $2.07 \mathrm{E}-08$ \\
\hline $\mathrm{Kr}-85$ & $2.454 \mathrm{E}-02$ & $2.0 \mathrm{E}+04$ & $2.8 \mathrm{E}+07$ & $1.23 \mathrm{E}-06$ & $8.76 \mathrm{E}-10$ \\
\hline Lu-177 & $1.426 \mathrm{E}-05$ & $3.4 \mathrm{E}+03$ & & 4.19E-09 & \\
\hline Mn-54 & $9.972 \mathrm{E}+00$ & $8.8 \mathrm{E}+02$ & & $1.13 \mathrm{E}-02$ & \\
\hline Мo-93 & $1.360 \mathrm{E}-02$ & $2.0 \mathrm{E}+03$ & & $6.80 \mathrm{E}-06$ & \\
\hline
\end{tabular}


INL/EXT-09-17427

Revision 0

Table 2. (continued).

\begin{tabular}{|c|c|c|c|c|c|}
\hline Isotope & $\begin{array}{l}\text { Maximum activity } \\
\text { concentration } \mathrm{Ci} / \mathrm{m}^{3}\end{array}$ & $\begin{array}{l}\mathrm{HC}-3 \mathrm{TQ} \\
(\mathrm{Ci})\end{array}$ & $\begin{array}{l}\text { HC-2 TQ } \\
(\mathrm{Ci})\end{array}$ & Fraction HC-3 & Fraction HC-2 \\
\hline $\mathrm{Nb}-93 \mathrm{~m}$ & $2.379 \mathrm{E}+00$ & $2.0 \mathrm{E}+03$ & & $1.19 \mathrm{E}-03$ & \\
\hline $\mathrm{Nb}-94$ & $2.000 \mathrm{E}+00$ & $2.0 \mathrm{E}+02$ & $8.6 \mathrm{E}+04$ & $1.00 \mathrm{E}-02$ & 2.33E-05 \\
\hline $\mathrm{Nb}-95$ & $4.875 \mathrm{E}+01$ & $9.6 \mathrm{E}+02$ & & $5.08 \mathrm{E}-02$ & \\
\hline $\mathrm{Nb}-95 \mathrm{~m}$ & 4.761E-01 & $5.60 \mathrm{E}+03$ & & $8.50 \mathrm{E}-05$ & \\
\hline $\mathrm{Ni}-59$ & $5.000 \mathrm{E}+02$ & $1.18 \mathrm{E}+04$ & & 4.24E-02 & \\
\hline Ni-63 & $5.500 \mathrm{E}+04$ & $5.4 \mathrm{E}+03$ & $4.5 \mathrm{E}+06$ & $1.02 \mathrm{E}+01$ & $1.22 \mathrm{E}-02$ \\
\hline Os-185 & $5.888 \mathrm{E}-05$ & $1.1 \mathrm{E}+03$ & & $5.35 \mathrm{E}-08$ & \\
\hline P-33 & $2.621 \mathrm{E}-04$ & $9.4 \mathrm{E}+01$ & $3.0 \mathrm{E}+04$ & $2.79 \mathrm{E}-06$ & 8.74E-09 \\
\hline $\mathrm{Pa}-233$ & $9.849 \mathrm{E}-06$ & $4.6 \mathrm{E}+03$ & & 2.14E-09 & \\
\hline $\mathrm{Pb}-212$ & $4.275 \mathrm{E}-06$ & $3.2 \mathrm{E}+02$ & & $1.34 \mathrm{E}-08$ & \\
\hline Pm-147 & $1.503 \mathrm{E}-01$ & $1.0 \mathrm{E}+03$ & $8.4 \mathrm{E}+05$ & $1.50 \mathrm{E}-04$ & $1.79 \mathrm{E}-07$ \\
\hline Pm-148m & 7.395E-06 & $3.6 \mathrm{E}+02$ & & $2.05 \mathrm{E}-08$ & \\
\hline Po-210 & $1.319 \mathrm{E}-04$ & $1.9 \mathrm{E}+00$ & $3.5 \mathrm{E}+02$ & $6.94 \mathrm{E}-05$ & $3.77 \mathrm{E}-07$ \\
\hline Pr-144 & $5.592 \mathrm{E}-02$ & $1.04 \mathrm{E}+06$ & & $5.38 \mathrm{E}-08$ & \\
\hline Ra-224 & $4.275 \mathrm{E}-06$ & $2.0 \mathrm{E}+02$ & $9.9 \mathrm{E}+03$ & $2.14 \mathrm{E}-08$ & $4.32 \mathrm{E}-10$ \\
\hline $\mathrm{Rb}-87$ & $2.975 \mathrm{E}-06$ & $6.0 \mathrm{E}+02$ & & 4.96E-09 & \\
\hline Re-188 & $8.959 \mathrm{E}-03$ & $2.2 \mathrm{E}+04$ & & 4.07E-07 & \\
\hline Rh-103m & $3.837 \mathrm{E}-04$ & $1.04 \mathrm{E}+07$ & & 3.69E-11 & \\
\hline Ru-103 & $3.837 \mathrm{E}-04$ & $1.56 \mathrm{E}+03$ & & $2.46 \mathrm{E}-07$ & \\
\hline $\mathrm{Ru}-106$ & $5.118 \mathrm{E}-02$ & $1.0 \mathrm{E}+02$ & $6.5 \mathrm{E}+03$ & 5.12E-04 & 7.87E-06 \\
\hline S-35 & $1.172 \mathrm{E}-01$ & $7.8 \mathrm{E}+01$ & $2.5 \mathrm{E}+04$ & $1.50 \mathrm{E}-03$ & $4.69 \mathrm{E}-06$ \\
\hline $\mathrm{Sb}-124$ & $6.22 \mathrm{E}-02$ & $3.6 \mathrm{E}+02$ & $1.3 \mathrm{E}+06$ & $1.73 \mathrm{E}-04$ & $4.78 \mathrm{E}-08$ \\
\hline Sb-125 & $5.780 \mathrm{E}+01$ & $1.2 \mathrm{E}+03$ & & 4.82E-02 & \\
\hline Sc-46 & 7.205E-03 & $3.6 \mathrm{E}+02$ & $1.4 \mathrm{E}+06$ & $2.00 \mathrm{E}-05$ & $5.15 \mathrm{E}-09$ \\
\hline Se-75 & $4.642 \mathrm{E}-03$ & $3.2 \mathrm{E}+02$ & $3.4 \mathrm{E}+05$ & $1.45 \mathrm{E}-05$ & $1.37 \mathrm{E}-08$ \\
\hline Se-79 & $2.975 \mathrm{E}-06$ & $3.6 \mathrm{E}+02$ & & 8.26E-09 & \\
\hline Sm-145 & $3.089 \mathrm{E}-03$ & $3.6 \mathrm{E}+03$ & & $8.58 \mathrm{E}-07$ & \\
\hline Sm-151 & $3.282 \mathrm{E}+01$ & $1.0 \mathrm{E}+03$ & $9.9 \mathrm{E}+05$ & $3.28 \mathrm{E}-02$ & 3.32E-05 \\
\hline Sn-113 & $4.328 \mathrm{E}+00$ & $1.3 \mathrm{E}+03$ & $3.2 \mathrm{E}+06$ & $3.33 \mathrm{E}-03$ & $1.35 \mathrm{E}-06$ \\
\hline Sn-119m & $7.886 \mathrm{E}+01$ & $1.86 \mathrm{E}+03$ & & 4.24E-02 & \\
\hline Sn-121 & $1.510 \mathrm{E}-01$ & $4.6 \mathrm{E}+04$ & & $3.28 \mathrm{E}-06$ & \\
\hline Sn-121m & $2.500 \mathrm{E}-01$ & $1.78 \mathrm{E}+03$ & & $1.40 \mathrm{E}-04$ & \\
\hline Sn-123 & $1.362 \mathrm{E}-02$ & $3.2 \mathrm{E}+02$ & & 4.26E-05 & \\
\hline Sr- 85 & $9.640 \mathrm{E}-05$ & $1.44 \mathrm{E}+04$ & & 6.69E-09 & \\
\hline Sr-89 & $2.073 \mathrm{E}-02$ & $3.4 \mathrm{E}+02$ & $7.7 \mathrm{E}+05$ & $6.10 \mathrm{E}-05$ & $2.69 \mathrm{E}-08$ \\
\hline Sr-90 & $5.000 \mathrm{E}+00$ & $1.6 \mathrm{E}+01$ & $2.2 \mathrm{E}+04$ & $3.13 \mathrm{E}-01$ & $2.27 \mathrm{E}-04$ \\
\hline Ta-182 & $1.196 \mathrm{E}+02$ & $6.2 \mathrm{E}+02$ & & $1.93 \mathrm{E}-01$ & \\
\hline Tb-160 & $1.614 \mathrm{E}-06$ & $5.6 \mathrm{E}+02$ & $1.3 \mathrm{E}+06$ & $2.88 \mathrm{E}-09$ & $1.24 \mathrm{E}-12$ \\
\hline Tc-99 & $6.000 \mathrm{E}-03$ & $1.7 \mathrm{E}+03$ & $3.8 \mathrm{E}+06$ & $3.53 \mathrm{E}-06$ & $1.58 \mathrm{E}-09$ \\
\hline $\mathrm{Te}-123 \mathrm{~m}$ & $8.257 \mathrm{E}-03$ & $4.0 \mathrm{E}+02$ & & $2.06 \mathrm{E}-05$ & \\
\hline Te-125m & $1.323 \mathrm{E}+01$ & $7.2 \mathrm{E}+02$ & & $1.84 \mathrm{E}-02$ & \\
\hline
\end{tabular}


INL/EXT-09-17427

Revision 0

Table 2. (continued).

\begin{tabular}{|l|c|c|c|c|c|}
\hline \multicolumn{1}{|c|}{ Isotope } & $\begin{array}{c}\text { Maximum activity } \\
\text { concentration Ci/m }\end{array}$ & $\begin{array}{c}\mathrm{HC}-3 \mathrm{TQ} \\
(\mathrm{Ci})\end{array}$ & $\begin{array}{c}\mathrm{HC}-2 \mathrm{TQ} \\
(\mathrm{Ci})\end{array}$ & Fraction HC-3 & Fraction HC-2 \\
\hline Te-127m & $2.085 \mathrm{E}-04$ & $4.0 \mathrm{E}+02$ & $1.5 \mathrm{E}+05$ & $5.21 \mathrm{E}-07$ & $1.39 \mathrm{E}-09$ \\
\hline Te-129 & $3.280 \mathrm{E}-06$ & $2.2 \mathrm{E}+05$ & & $1.49 \mathrm{E}-11$ & \\
\hline Te-129m & $4.275 \mathrm{E}-06$ & $4.0 \mathrm{E}+02$ & $1.4 \mathrm{E}+05$ & $1.07 \mathrm{E}-08$ & $3.05 \mathrm{E}-11$ \\
\hline Th-228 & $4.275 \mathrm{E}-06$ & $1.0 \mathrm{E}+00$ & $9.2 \mathrm{E}+01$ & $4.28 \mathrm{E}-06$ & $4.65 \mathrm{E}-08$ \\
\hline Th-234 & $4.420 \mathrm{E}-06$ & $2.8 \mathrm{E}+03$ & & $1.58 \mathrm{E}-09$ & \\
\hline U-232 & $5.369 \mathrm{E}-06$ & $8.2 \mathrm{E}-01$ & & $6.55 \mathrm{E}-06$ & \\
\hline U-234 & $4.419 \mathrm{E}-06$ & $4.2 \mathrm{E}+00$ & $2.2 \mathrm{E}+02$ & $1.05 \mathrm{E}-06$ & $2.01 \mathrm{E}-08$ \\
\hline U-237 & $2.335 \mathrm{E}-06$ & $1.44 \mathrm{E}+04$ & & $1.62 \mathrm{E}-10$ & \\
\hline U-238 & $4.419 \mathrm{E}-06$ & $4.2 \mathrm{E}+00$ & $2.4 \mathrm{E}+02$ & $1.05 \mathrm{E}-06$ & $1.84 \mathrm{E}-08$ \\
\hline W-181 & $2.669 \mathrm{E}-02$ & $1.3 \mathrm{E}+04$ & & $2.05 \mathrm{E}-06$ & \\
\hline W-185 & $1.301 \mathrm{E}-01$ & $1.38 \mathrm{E}+03$ & & $9.43 \mathrm{E}-05$ & \\
\hline Y-90 & $5.000 \mathrm{E}+00$ & $1.42 \mathrm{E}+03$ & & $3.52 \mathrm{E}-03$ & \\
\hline Y-91 & $1.078 \mathrm{E}-01$ & $3.6 \mathrm{E}+02$ & $6.5 \mathrm{E}+05$ & $2.99 \mathrm{E}-04$ & $1.66 \mathrm{E}-07$ \\
\hline Zn-65 & $3.908 \mathrm{E}-02$ & $2.4 \mathrm{E}+02$ & $1.6 \mathrm{E}+06$ & $1.63 \mathrm{E}-04$ & $2.44 \mathrm{E}-08$ \\
\hline Zr-93 & $3.231 \mathrm{E}-02$ & $6.2 \mathrm{E}+01$ & $8.9 \mathrm{E}+04$ & $5.21 \mathrm{E}-04$ & $3.63 \mathrm{E}-07$ \\
\hline Zr-95 & $2.268 \mathrm{E}+01$ & $7.0 \mathrm{E}+02$ & $1.5 \mathrm{E}+06$ & $3.24 \mathrm{E}-02$ & $1.51 \mathrm{E}-05$ \\
\hline & & & HC-3 & HC-2 \\
\hline \multicolumn{7}{|l|}{ Sum of the Fractions $/ \mathbf{m}^{3}$} & $4.75 \mathrm{E}+01$ & $6.57 \mathrm{E}-02$ \\
\hline
\end{tabular}

The data in Table 2 is very conservative as these values are shown as maximum curie quantities per cubic meter of waste. However, projected remote-handled LLW generation for disposal is significant, at $1,649 \mathrm{~m}^{3}$ by the year 2037, giving a substantial isotope inventory in the facility. By acceptance of approximately $15 \mathrm{~m}^{3}$ of waste at or near the maximum concentrations shown above, the facility would exceed HC-2 threshold quantities.

\subsection{Comparison of Inventories to Threshold Quantities}

Based on the preliminary assessment of the estimated inventory in the bounding remote-handled LLW waste stream (Table 2) and comparison with DOE-STD-1027-92, the proposed Remote-Handled LLW Disposal Facility would have a radionuclide inventory which, if evaluated in its entirety, would result in an initial hazard categorization as a HC-2 nuclear facility. However, DOE-STD-1027 supplemental guidance provides for facility categorization being modified in the final hazard categorization process considering, 1) alternative release fractions, or 2) change in material subject to an accident due to facility features which preclude bringing material together or causing harmful interaction from a common severe phenomenon (facility segmentation). These provisions will be further evaluated during the development of the preliminary documented safety analysis (PDSA) and documented safety analysis (DSA) per NS-18101, "INL Safety Analysis Process," to determine if modification to the preliminary facility hazard category is appropriate based on alternative release fractions and facility segmentation considerations. If the segmented facility consideration is successful, the facility may be categorized based on the contents of a single vault and using the isotope values shown in Table 2 . Such a categorization may result in a reduced facility hazard category. 


\section{DESIGN BASIS ACCIDENTS}

The list of potential hazards identified in the preliminary hazard assessment (PHA) is to be used as an outline for the development of a hazards assessment and facility safety basis documents. It incorporates extensive experience and lessons learned from similar facility nuclear safety designs and operations. The current stage of the conceptual design process requires a preliminary identification of hazards and DBAs and the need for safety structures, systems, and components (SSCs). Further detailed analyses will be completed in conjunction with development of the PDSA.

The waste liners associated with the various remote-handled LLW waste streams are anticipated to contain irradiated hardware, highly radioactive process materials, or nuclear reactor system resins. Though some variability in form is expected, most of the radioactive material will be in the form of irradiated solids or ion exchange resin with contaminants attached to the resin particle surface. Radioactive liquids are specifically prohibited from these waste streams, and combustible materials in the waste streams are known to exist only in very small quantities.

\subsection{Facility-Level DBAs}

A qualitative hazard evaluation is performed for the hazards that can result in an uncontrolled release of radioactive or hazardous material and affect the off-site public, collocated workers, facility workers, or the environment. In performing this qualitative evaluation of hazardous events, the location, hazard, initiating conditions, likelihood, unmitigated consequences, and preventive and mitigative features are considered.

The likelihood category reflects a qualitative estimate of whether the hazardous event is anticipated (A), unlikely (U), extremely unlikely (EU), or beyond extremely unlikely (BEU) using the definitions in Table 3 (ref. NS-18104, "Nuclear Safety Engineering"). The likelihood of a hazardous event is generally the frequency of the initiating event or cause. No credit is taken for controls (i.e., design or administrative) which prevent the event. For an internal event (i.e., events initiated by equipment failure or human error), this generally results in a likelihood category of anticipated (i.e., $10^{-2}$ to $10^{-1}$ per year) since the frequency can depend on the facility design and operation. The likelihood category is based on available data, operating experience, and/or engineering judgment. If there is uncertainty in the likelihood category, the higher likelihood category is conservatively assumed. 
INL/EXT-09-17427

Revision 0

Table 3. Qualitative likelihood category for potential hazardous events.

\begin{tabular}{|c|c|c|}
\hline Likelihood Category & Description & $\begin{array}{c}\text { Frequency of Occurrence } \\
\text { (per year) }\end{array}$ \\
\hline Anticipated (A) & $\begin{array}{l}\text { Events that have occurred or are } \\
\text { expected to occur during the } \\
\text { lifetime of the facility (frequency } \\
\text { between once in } 10 \text { and once in } \\
100 \text { years). }\end{array}$ & $10^{-2}$ to $10^{-1}$ \\
\hline Unlikely (U) & $\begin{array}{l}\text { Events that may occur but are not } \\
\text { anticipated in the lifetime of the } \\
\text { facility (frequency between once } \\
\text { in } 100 \text { and once in } 10,000 \text { years). }\end{array}$ & $10^{-4}$ to $10^{-2}$ \\
\hline Extremely Unlikely (EU) & $\begin{array}{l}\text { Events that while possible will } \\
\text { probably not occur in the lifetime } \\
\text { of the facility (frequency } \\
\text { between once in } 10,000 \text { and once } \\
\text { in a million years). }\end{array}$ & $10^{-6}$ to $10^{-4}$ \\
\hline $\begin{array}{l}\text { Beyond Extremely Unlikely } \\
\text { (BEU) }\end{array}$ & $\begin{array}{l}\text { Events that are considered too } \\
\text { improbable to warrant further } \\
\text { consideration (frequency less } \\
\text { than once in a million years). }\end{array}$ & less than $10^{-6}$ \\
\hline
\end{tabular}

The consequence category reflects a qualitative estimate of potential consequences to the off-site public, collocated workers, facility workers, and environment from the hazardous event using the guidelines in Table 4. A consequence category of high $(\mathrm{H})$, moderate $(\mathrm{M})$, low $(\mathrm{L})$, or negligible $(\mathrm{N})$ is assigned for each receptor and the environment based on the unmitigated quantity of radioactive and/or hazardous material potentially released and the energy source for dispersion. Unmitigated means that a material's quantity, form, location, dispersibility, and interaction with available energy sources are considered, but no credit is taken for safety features (e.g., ventilation system, fire suppression) which could mitigate a hazard. Where DBAs do not exist or do not cover the range of scenarios or bounding conditions, surrogate evaluation bases (i.e., derivative DBAs) are needed. These derivative DBAs are used to evaluate the response of SSCs to the range of accident scenarios and stresses that bound the envelope of accident conditions to which the facility could be subjected. If there is uncertainty in the consequence category, the more severe consequence category is conservatively assumed. 
INL/EXT-09-17427

Revision 0

Table 4. Qualitative consequence category.

\begin{tabular}{|l|c|c|c|l|}
\hline $\begin{array}{c}\text { Consequence } \\
\text { Category }\end{array}$ & Off-Site Public & $\begin{array}{c}\text { On-Site (Collocated) } \\
\text { Workers }\end{array}$ & Facility Workers & \multicolumn{1}{|c|}{ Environment } \\
\hline High (H) & $\begin{array}{c}\text { Greater than } 25 \\
\text { rem }\end{array}$ & Greater than $100 \mathrm{rem}$ & Greater than $100 \mathrm{rem}$ & $\begin{array}{l}\text { Off-site contamination or } \\
\text { major liquid release to the } \\
\text { groundwater }\end{array}$ \\
\hline Moderate (M) & $5 \mathrm{rem}$ to $25 \mathrm{rem}$ & $25 \mathrm{rem}$ to $100 \mathrm{rem}$ & $25 \mathrm{rem}$ to $100 \mathrm{rem}$ & INL sitewide contamination \\
\hline Low (L) & $0.5 \mathrm{rem}$ to $5 \mathrm{rem}$ & $5 \mathrm{rem}$ to $25 \mathrm{rem}$ & $5 \mathrm{rem}$ to $25 \mathrm{rem}$ & $\begin{array}{l}\text { Site area contamination } \\
\text { outside the facility }\end{array}$ \\
\hline Negligible (N) & Less than $0.5 \mathrm{rem}$ & Less than $5 \mathrm{rem}$ & Less than $5 \mathrm{rem}$ & $\begin{array}{l}\text { No contamination outside } \\
\text { the facility }\end{array}$ \\
\hline
\end{tabular}

Table 5 is a summary table identifying postulated hazardous material release and direct radiation exposure events for the proposed Remote-Handled LLW Disposal Facility. 


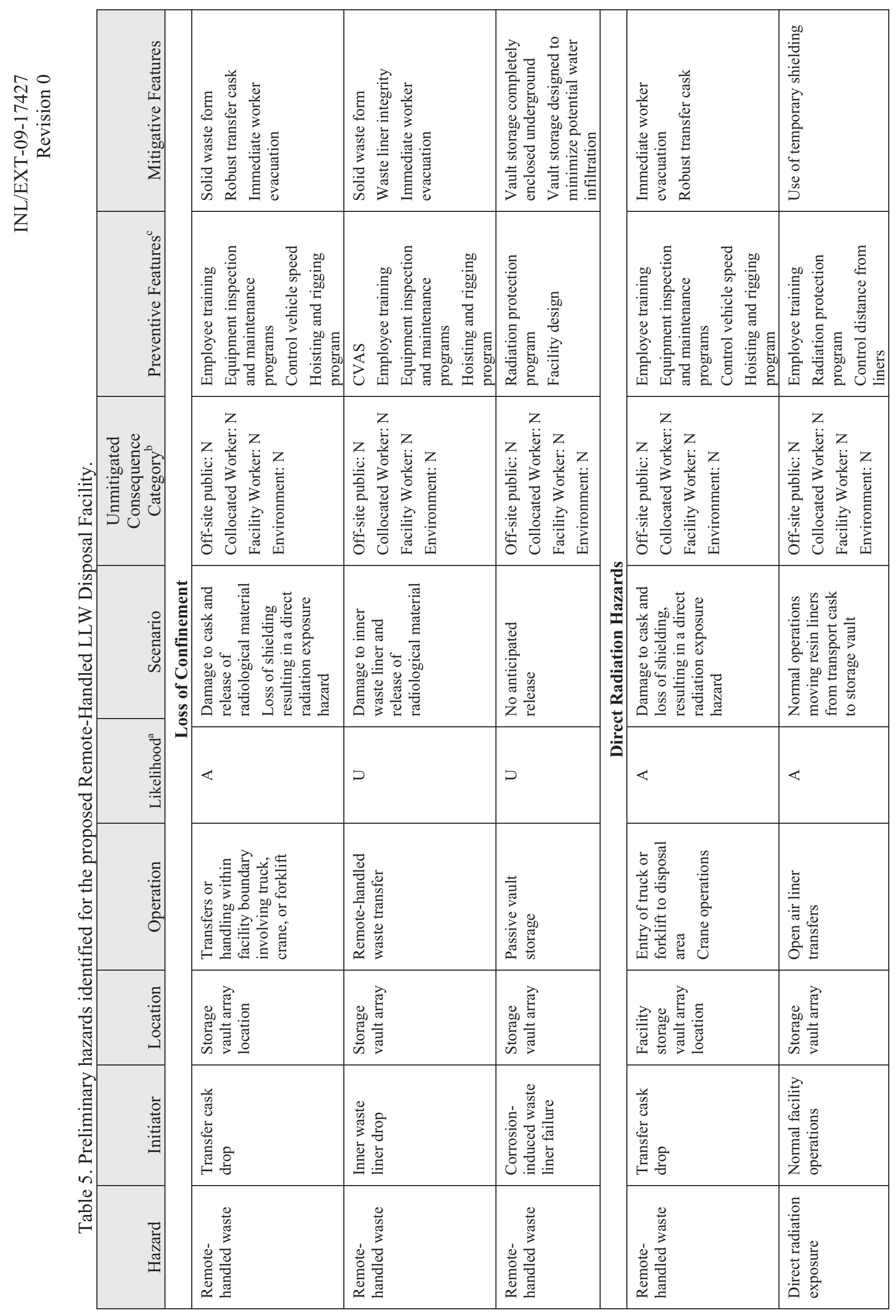




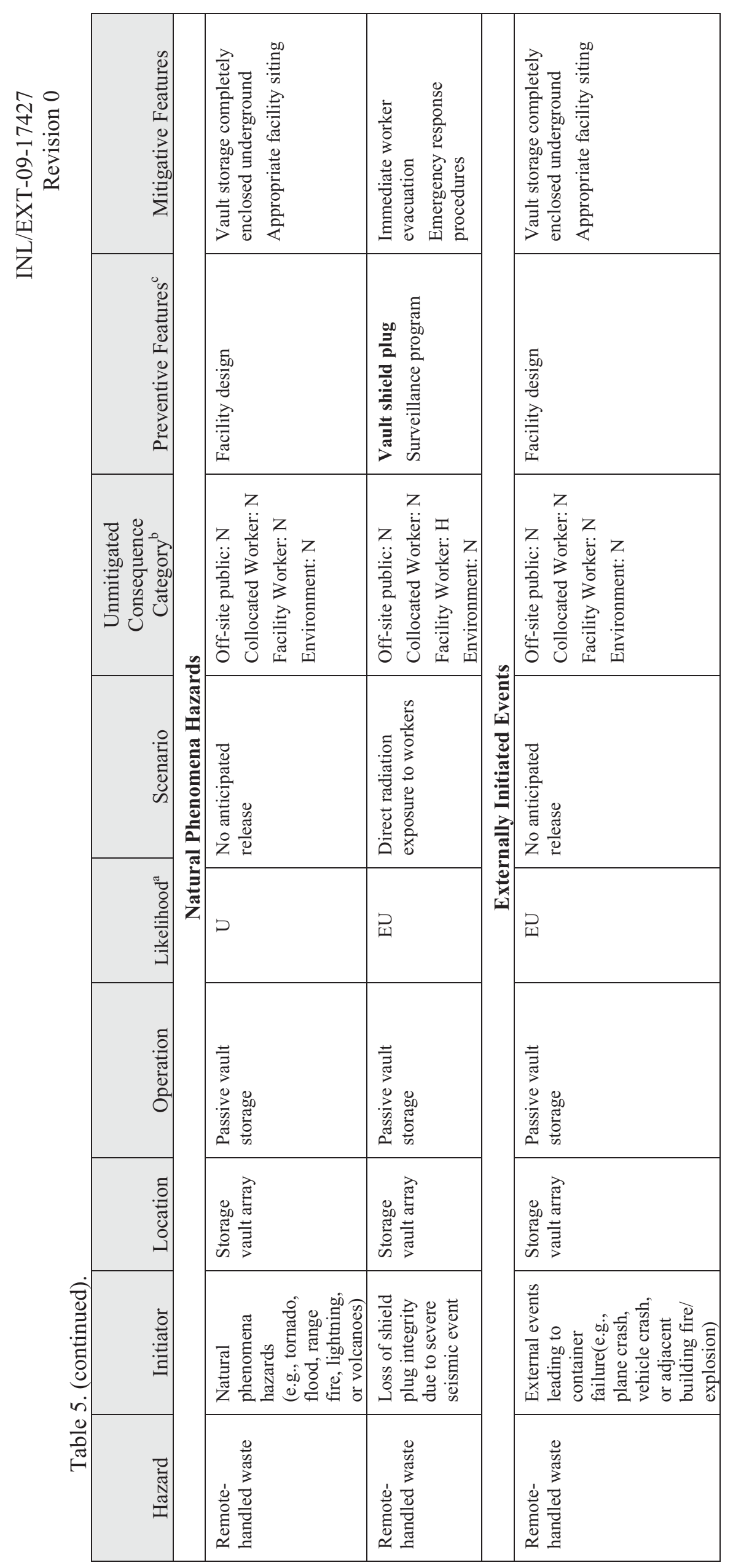




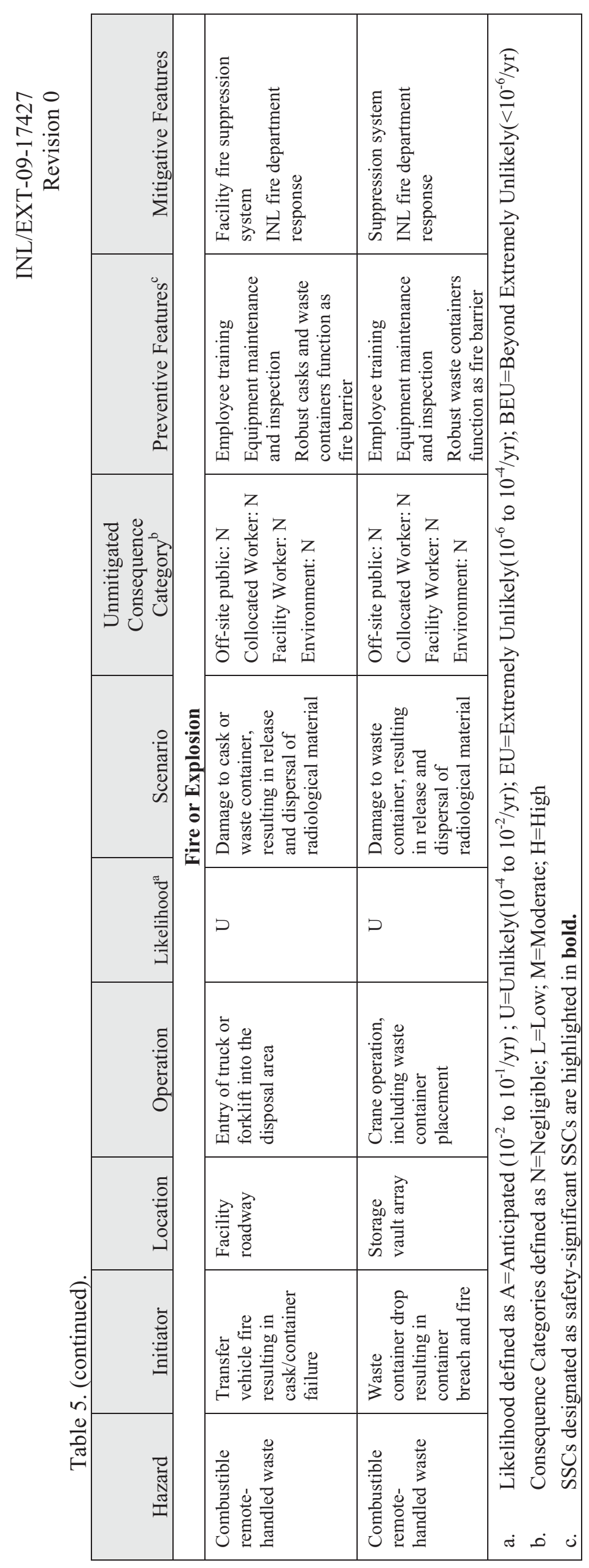


Figure 8 through Figure 10 are qualitative risk matrices (ref. NS-18104) to be used for deriving the need for safety-class or safety-significant SSCs for the off-site public, collocated worker, and facility worker, respectively. Locating the point on the appropriate matrix which corresponds to the likelihood category and consequence category from each postulated accident determines if safety SSCs or safety analysis commitments are required as a control for that accident. For each of the identified DBAs, the consequence and likelihood were identified and compared to the intersect in the appropriate risk matrix below. 
INL/EXT-09-17427

Revision 0

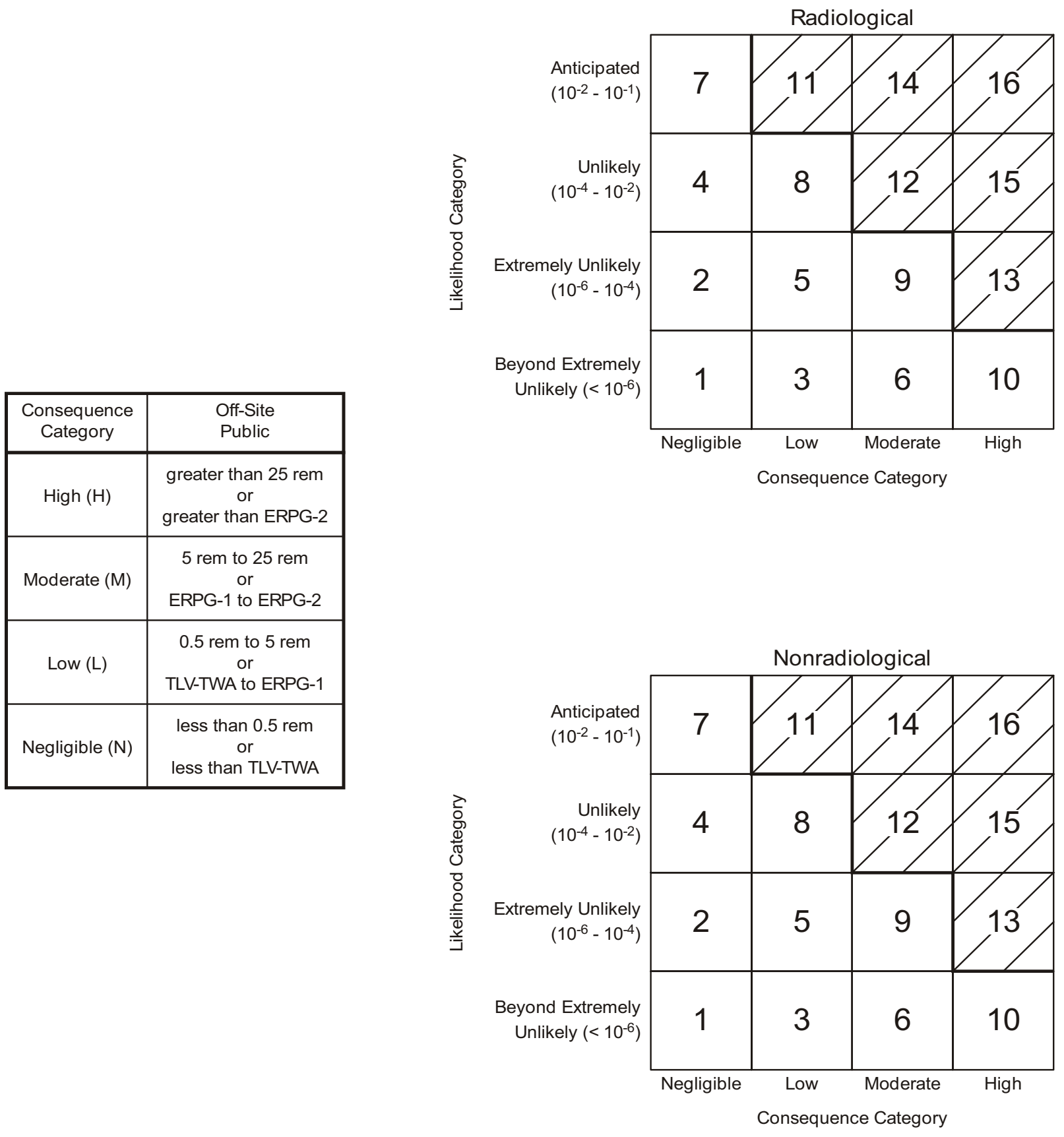

KEY

Safety-class SSCs and/or TSRs should be identified to manage off-site public risk;

accident analysis may be needed.

Safety-class SSCs or TSRs are generally not required to manage off-site public risk.

02-GA51330-01

Figure 8. Qualitative risk matrix for the off-site public. 
INL/EXT-09-17427

Revision 0

\begin{tabular}{|c|c|}
\hline $\begin{array}{c}\text { Consequence } \\
\text { Category }\end{array}$ & $\begin{array}{c}\text { On-Site } \\
\text { (Collocated) Workers }\end{array}$ \\
\hline High (H) & $\begin{array}{c}\text { greater than } 100 \text { rem } \\
\text { or } \\
\text { greater than ERPG-3 } \\
\text { or } \\
\text { greater th an } \triangle 25 \text { psi }\end{array}$ \\
\hline Moderate (M) & $\begin{array}{c}25 \text { rem to } 100 \text { rem } \\
\text { or } \\
\text { ERPG-2 to ERPG-3 }\end{array}$ \\
\hline Low (L) & $\begin{array}{c}5 \text { rem to 25 rem } \\
\text { or } \\
\text { ERPG-1 to ERPG-2 }\end{array}$ \\
\hline Negligible (N) & $\begin{array}{c}\text { less than } 5 \text { rem } \\
\text { or } \\
\text { less than ERPG-1 }\end{array}$ \\
\hline
\end{tabular}
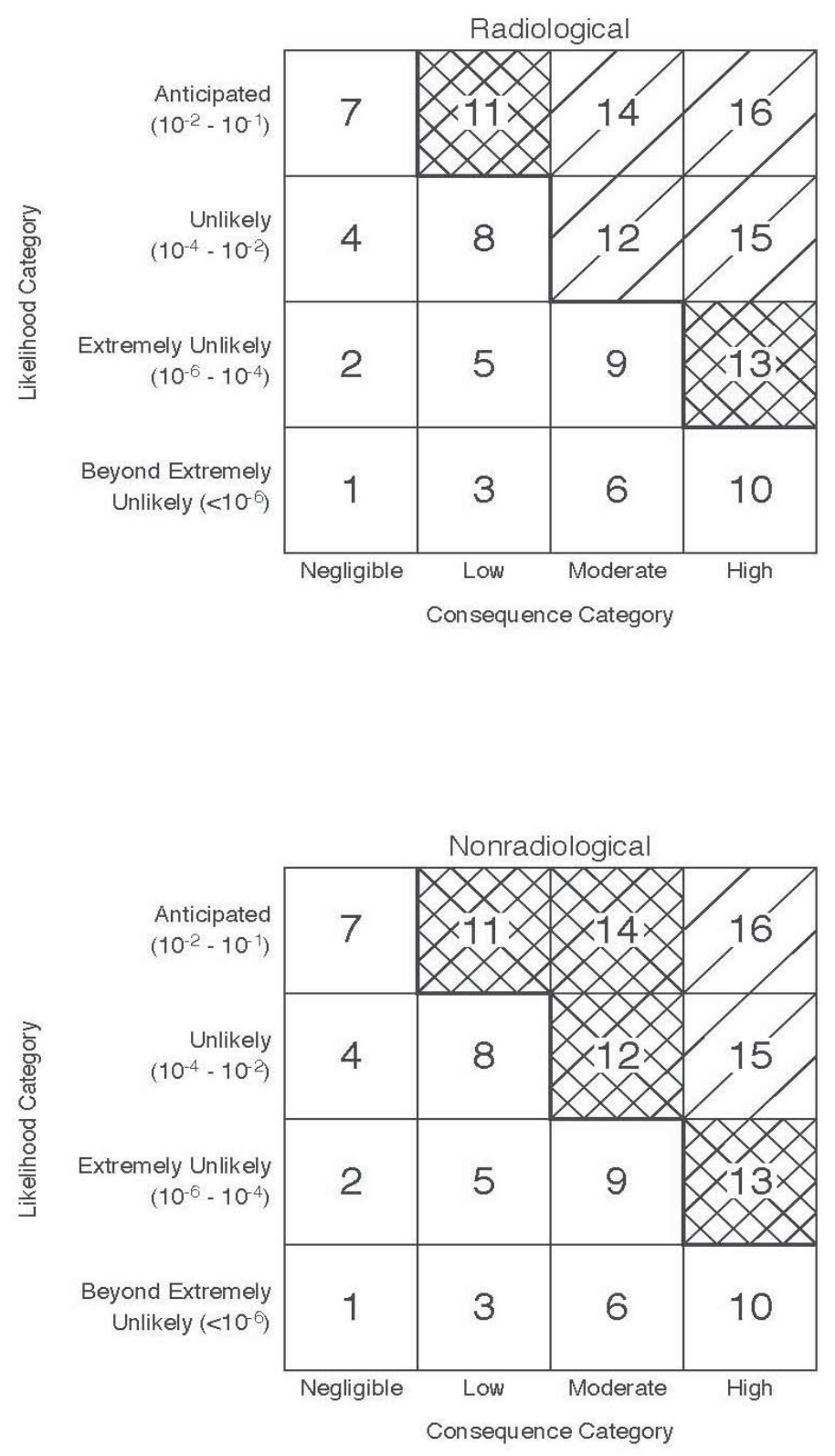

KEY

Safety-significant SSCs and/or TSRs should be identified to manage collocated worker risk; accident analysis may be needed.

Safety analysis commitments should be identified to manage collocated worker risk.

Safety SSCs, TSRs, or safety analysis commitments are generally not required to manage collocated worker risk.

Figure 9. Qualitative risk matrix for collocated workers. 
INL/EXT-09-17427

Revision 0

\begin{tabular}{|c|c|}
\hline $\begin{array}{c}\text { Consequence } \\
\text { Category }\end{array}$ & $\begin{array}{c}\text { Facility } \\
\text { Workers }\end{array}$ \\
\hline High (H) & $\begin{array}{c}\text { greater than } 100 \text { rem } \\
\text { or } \\
\text { greater than ERPG-3 } \\
\text { or } \\
\text { greater than } \triangle 25 \text { psi }\end{array}$ \\
\hline Moderate (M) & $\begin{array}{c}25 \text { rem to } 100 \text { rem } \\
\text { or } \\
\text { ERPG-2 to ERPG-3 }\end{array}$ \\
\hline Low (L) & $\begin{array}{c}5 \text { rem to } 25 \text { rem } \\
\text { or } \\
\text { ERPG-1 to ERPG-2 }\end{array}$ \\
\hline Negligible (N) & $\begin{array}{c}\text { less than } 5 \text { rem } \\
\text { or } \\
\text { less than ERPG-1 }\end{array}$ \\
\hline
\end{tabular}
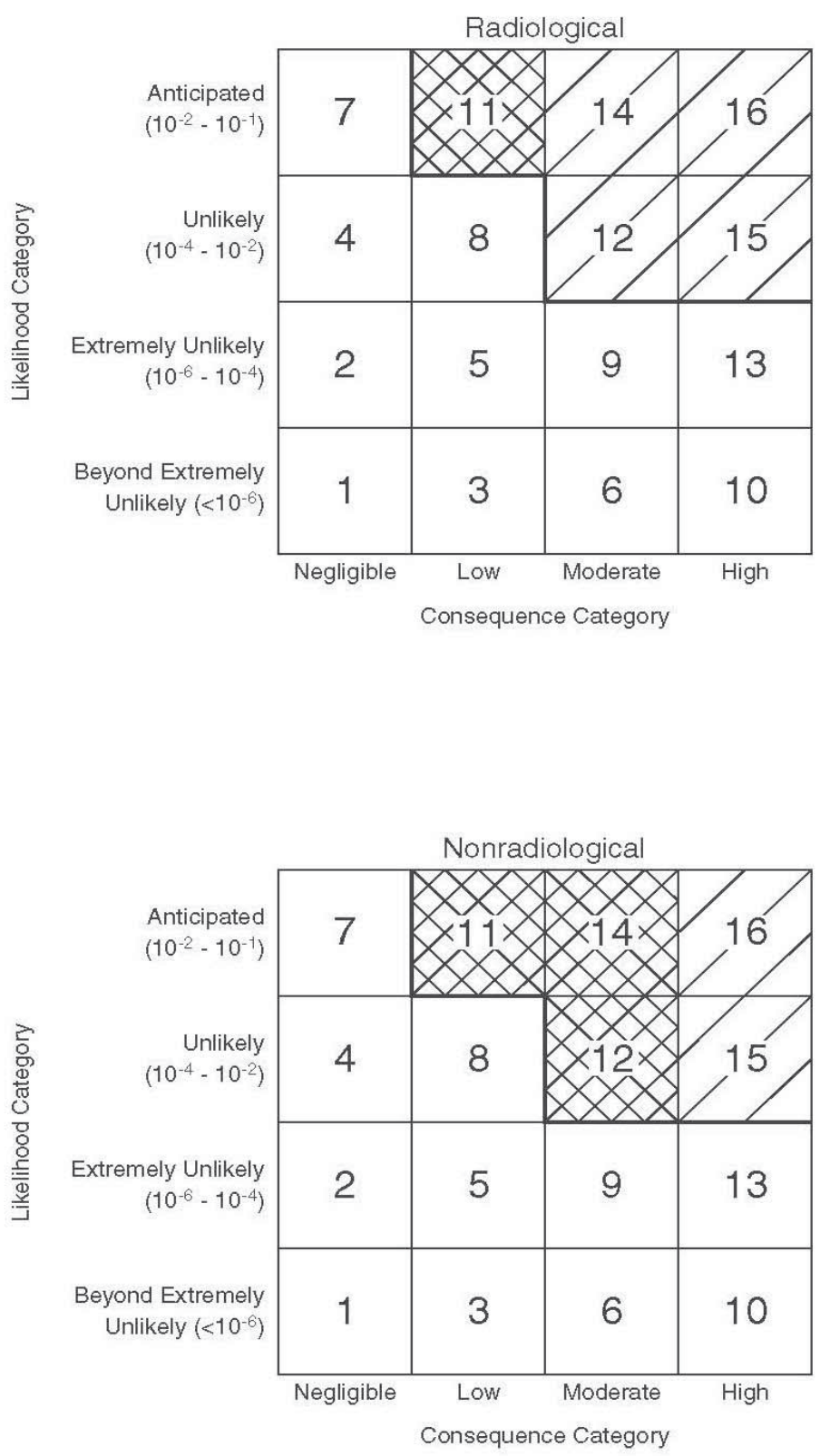

KEY

Safety-significant SSCs and/or TSRs should be identified to manage facility worker risk.

Safety analysis commitments should be identified to manage facility worker risk.

Safety SSCs, TSRs, or safety analysis commitments are generally not required to manage facility worker risk.

Figure 10. Qualitative risk matrix for facility workers. 


\subsection{Unmitigated DBA Analyses}

The unmitigated analyses for the DBAs are summarized in the following sections. The accidents considered here are used to determine if safety SSCs would be considered at this stage of facility design and are preliminary in nature. Experience in other underground waste disposal facilities indicates that these events typically represent the highest risk in terms of likelihood and consequence. During subsequent safety document development, these accidents will be further evaluated, documented, and peer reviewed.

\subsubsection{Container Drop Accident (cask or free-air transfer drop)}

Initially this accident was considered in the PHA preliminary hazards identification table as separate events for transfer cask drop and waste liner drop. The consequences of either event are the same, and these events will be considered together in this evaluation.

This DBA event involves dropping a liner or cask that results in the release of radioactive material. The NRF scrap cask is lifted from the transport vehicle utilizing the facility crane. It is also anticipated that ATR resin liners and INL activated metal liners will be "open air" transferred from the top-load shipping cask to the vault utilizing the facility crane. The drop of a liner or cask results from failure of the crane, lifting and handling equipment, liner, or cask and is considered an anticipated event for the proposed facility. In this postulated event, the waste liner or cask is dropped to the ground breaching multiple layers of confinement and releasing radioactive material.

Dose to the worker in this case is from both uptake of radioactive material and from direct exposure to the unshielded and high radiation levels associated with this material.

The material-at-risk (MAR) in this scenario is limited to the contents of a single liner. An unmitigated analysis is performed for which the hazardous material's quantity, form, location, dispersibility, and interaction with available energy are considered, but no credit is taken for safety features which could mitigate the consequences of a hazard. The bounding IWTS waste stream profile "2534: NRF 55-ton scrap cask insert with remote handled low level waste" shows the maximum Co-60 loading at $10,000 \mathrm{Ci} / \mathrm{m}^{3}$. Container profiles in this waste stream show volume to be approximately 703 gallons $\left(2.66 \mathrm{~m}^{3}\right)$. For the unmitigated analysis for this accident, $26,600 \mathrm{Ci}$ of Co-60 is assumed as the MAR $\left(10,000 \mathrm{Ci} / \mathrm{m}^{3} \times 2.66 \mathrm{~m}^{3}\right)$. In the waste stream shown in Table 2, only two isotopes exceed HC-3 TQs: Co-60 and Ni-63. The inhalation dose for Co-60 is far greater than that of Ni-63. For the purpose of this preliminary dose consequence analysis, MAR is conservatively assumed to be composed entirely of Co-60 at the maximum level.

Values used to calculate a source term for uptake in this accident are:

Damage ratio $(\mathrm{DR})=0.1$

Airborne release fraction $(\mathrm{ARF})=1.0 \mathrm{E}-3$

Respirable fraction $(\mathrm{RF})=1.0$

Leak path factor $(\mathrm{LPF})=1.0$

The DR of 0.1 is conservatively derived, based on engineering judgment of the amount of material ejected from a breached container that contains activated metals in solid form, after a drop. 
The ARF and RF were taken from DOE-HDBK-3010-2004, "Airborne Release Fractions/Rates and Respirable Fractions for Nonreactor Nuclear Facilities," (p. 5-7) and are applicable to solids that experience predominantly plastic deformation (e.g., metal, plastics) as opposed to brittle fracture, responding to vibration and shock of the substrate by flexing. Materials adhering to the surface are ejected by the movement depending on how the contaminant is attached to the surface, where nominal airflow in facilities or outdoors act on powders on unyielding surfaces. These values are considered conservative for the accident and are most applicable to the debris or resin waste. Activated hardware waste streams would have ARF and RF values much lower than these.

A leak path factor of 1.0 is a standard assumption for DOE facilities and activities and is appropriate for an outdoor event such as what is being evaluated.

The calculated source term (ST) is found by multiplying the above factors as follows:

$$
\begin{aligned}
& \mathrm{ST}=\mathrm{MAR} \times \mathrm{DR} \times \mathrm{ARF} \times \mathrm{RF} \times \mathrm{LPF} \\
& \mathrm{ST}=26,600 \mathrm{Ci} \times 0.1 \times 1.0 \mathrm{E}-3 \times 1.0 \times 1.0=2.66 \mathrm{Ci}
\end{aligned}
$$

Dose consequences are calculated as follows

Dose $($ Rem $)=\mathrm{ST} \times$ breathing rate $\times$ dose conversion factor $(\mathrm{DCF}) \times \chi / \mathrm{Q}$

Using appropriate values for each factor gives doses from uptake of Co-60 at $30 \mathrm{~m}$ for the facility worker, $100 \mathrm{~m}$ for collocated worker, and an assumed 5,000 $\mathrm{m}$ for the off-site public maximally exposed

\begin{tabular}{|c|c|c|c|c|c|c|c|c|c|c|}
\hline \multirow[b]{2}{*}{$\begin{array}{l}\text { Source } \\
\text { term } \\
\text { (CI) }\end{array}$} & \multirow[b]{2}{*}{$\begin{array}{c}\text { Breathing } \\
\text { rate } \\
\left(\mathrm{m}^{3} / \mathrm{s}\right) \\
\end{array}$} & \multicolumn{3}{|c|}{$\begin{array}{l}\text { Facility } \\
\text { worker }\end{array}$} & \multicolumn{3}{|c|}{$\begin{array}{c}\text { Collocated } \\
\text { worker }\end{array}$} & \multicolumn{3}{|c|}{$\begin{array}{l}\text { Offsite } \\
\text { public }\end{array}$} \\
\hline & & $\chi / \mathrm{Q}\left(\mathrm{s} / \mathrm{m}^{3}\right)$ & $\begin{array}{c}\text { Inhaled } \\
\text { DCF } \\
(\mathrm{rem} / \mathrm{Ci}) \\
\end{array}$ & Dose (rem) & $x / \mathrm{Q}\left(\mathrm{s} / \mathrm{m}^{3}\right)$ & $\begin{array}{c}\text { Inhaled DCF } \\
\text { (rem/Ci) }\end{array}$ & Dose (rem) & $\chi / \mathrm{Q}\left(\mathrm{s} / \mathrm{m}^{3}\right)$ & $\begin{array}{c}\text { Inhaled } \\
\text { DCF } \\
(\mathrm{rem} / \mathrm{Ci}) \\
\end{array}$ & Dose (rem) \\
\hline $2.66 \mathrm{E}+00$ & 3.33E-04 & $3.73 \mathrm{E}-02$ & $6.29 \mathrm{E}+04$ & $2.08 \mathrm{E}+00$ & $4.08 \mathrm{E}-03$ & $6.29 \mathrm{E}+04$ & $2.27 \mathrm{E}-01$ & $5.70 \mathrm{E}-05$ & $1.29 \mathrm{E}+04$ & $6.51 \mathrm{E}-04$ \\
\hline
\end{tabular}
individual:

Breathing rate is the assumed breathing rate described in DOE O 440.1B, "Worker Protection Program for DOE." DCFs are published in ICRP-68, "Dose Coefficients for Intakes of Radionuclides by Workers," for workers and ICRP-72, "Age-dependent Doses from Intakes of Radionuclides," for the public. The airborne dispersion value for $\chi / \mathrm{Q}$ was obtained from RSAC-7 modeling using 95 percentile meteorological conditions appropriate for INL.

Dose from direct radiation exposure may be calculated using the maximum anticipated dose rate expected at the Remote-Handled LLW Disposal Facility of 30,000 R/hr at near-contact, then calculated to the positions of the facility worker and collocated worker.

Assuming a point source, the dose is reduced at the rate of the inverse to the square of the distance as shown in the inverse square law:

$I_{1} / I_{2}=\left(r_{2} / r_{1}\right)^{2}$, where $I$ is radiation intensity and $r$ is distance from the source. 
Assuming the radiation intensity of the dropped waste liner is $30,000 \mathrm{R} / \mathrm{hr}$ at $0.1 \mathrm{~m}$ as a point source, then at $30 \mathrm{~m}$ :

$30000 /(30 / 0.1)^{2}=33 \mathrm{R} / \mathrm{hr}$ to the worker and

$30000 /(100 / 0.1)^{2}=0.03 \mathrm{R} / \mathrm{hr}$ to the collocated worker.

Assuming an evacuation time of two minutes for this postulated event, dose to the facility worker and collocated worker is calculated as follows:

Dose rate $(\mathrm{R} / \mathrm{hr}) \times 2 \mathrm{~min} / 60 \mathrm{~min} / \mathrm{hr}$

and

$33 \mathrm{R} / \mathrm{hr} \times 2 \mathrm{~min} / 60 \mathrm{~min} / \mathrm{hr}=1.1 \mathrm{R}$, roughly equivalent to $1 \mathrm{rem}$ to the facility worker

and

$0.03 \mathrm{R} / \mathrm{hr} \times 2 \mathrm{~min} / 60 \mathrm{~min} / \mathrm{hr}=0.001 \mathrm{R}$, roughly equivalent to $0.001 \mathrm{rem}$ to the collocated worker.

Dose rates to the public from direct radiation at an assumed 5,000 $\mathrm{m}$ would be negligible based on the negligible dose at $100 \mathrm{~m}$ for the collocated worker.

Dose consequence evaluation guidelines for the public and facility workers are 0.5 rem and 5 rem, respectively, for anticipated events. As can be seen in the evaluation of dose to public and workers, the dose consequence is negligible to the public and low to the workers for this event when considering both dose from uptake of radioactive material and direct radiation exposure.

\subsubsection{Vehicle Fuel Fire Release Accident}

The lifting and handling of casks and waste liners would require the use of trucks, tractor/trailer combinations, and a crane. These vehicles introduce the potential for a vehicle fire that is postulated to occur during transport or during cask/liner unloading evolutions. Such a fire is postulated to initiate from fuel from the transport vehicle or crane and entirely engulfs the cask/liner being transported or unloaded, resulting in volatilization of a fraction of the waste material being handled. Given the nature of this waste, very small amounts of flammable material will actually be disposed in the waste stream. This accident analysis considers only that material which is affected by the thermal stresses from the fire as container boundaries are breached. Material already in storage is not involved in this accident. The likelihood of this accident is judged as unlikely.

Dose to the facility worker, collocated worker, and public in this case is assumed to be only from intake of radiological material made airborne in the fire.

The MAR in this scenario is limited to the contents of a single liner. The unmitigated analysis performed for this event again gives no credit for safety features which could mitigate the consequences. Again, for the unmitigated analysis, 26,600 $\mathrm{Ci}$ of Co-60 is assumed as the MAR. 
Values used to calculate the source term for uptake in this accident are:

$$
\begin{aligned}
& \mathrm{DR}=0.1 \\
& \mathrm{ARF}=6.0 \mathrm{E}-3 \\
& \mathrm{RF}=0.01 \\
& \mathrm{LPF}=1.0
\end{aligned}
$$

The DR of 0.1 is based on engineering judgment of the amount of material impacted from an engulfing fire where the source material contains low amounts of combustibles and originates within multiple layers of protection.

The ARF and RF were taken from DOE-HDBK-3010-2004 (p. 5-21) and are applicable to noncombustible solids with unyielding surfaces that experience thermal stress. Materials adhering to the surface are ejected by the expansion and contraction of the material during heating and oxidation.

Leak path factor of 1.0 is a standard assumption for DOE facilities and activities and is appropriate for an outdoor event such as what is being evaluated.

The calculated ST is found by multiplying the above factors as follows:

$$
\begin{aligned}
& \mathrm{ST}=\mathrm{MAR} \times \mathrm{DR} \times \mathrm{ARF} \times \mathrm{RF} \times \mathrm{LPF} \\
& \mathrm{ST}=0.16 \mathrm{Ci}=26,600 \mathrm{Ci} \times 0.1 \times 6.0 \mathrm{E}-3 \times 0.01 \times 1.0
\end{aligned}
$$

\begin{tabular}{|c|c|c|c|c|c|c|c|c|c|c|}
\hline \multirow[b]{2}{*}{$\begin{array}{l}\text { Source } \\
\text { term } \\
\text { (CI) }\end{array}$} & \multirow[b]{2}{*}{$\begin{array}{c}\text { Breathing } \\
\text { rate } \\
\left(\mathrm{m}^{3} / \mathrm{s}\right)\end{array}$} & \multicolumn{3}{|c|}{$\begin{array}{l}\text { Facility } \\
\text { worker }\end{array}$} & \multicolumn{3}{|c|}{$\begin{array}{c}\text { Collocated } \\
\text { worker }\end{array}$} & \multicolumn{3}{|c|}{$\begin{array}{l}\text { Offsite } \\
\text { public }\end{array}$} \\
\hline & & $\chi / \mathrm{Q}\left(\mathrm{s} / \mathrm{m}^{3}\right)$ & $\begin{array}{l}\text { Inhaled } \\
\text { DCF } \\
(\mathrm{rem} / \mathrm{Ci}) \\
\end{array}$ & Dose (rem) & $\chi / \mathrm{Q}\left(\mathrm{s} / \mathrm{m}^{3}\right)$ & $\begin{array}{c}\text { Inhaled DCF } \\
\text { (rem/Ci) }\end{array}$ & Dose (rem) & $\chi / \mathrm{Q}\left(\mathrm{s} / \mathrm{m}^{3}\right)$ & $\begin{array}{c}\text { Inhaled } \\
\text { DCF } \\
(\mathrm{rem} / \mathrm{Ci}) \\
\end{array}$ & Dose (rem) \\
\hline $1.60 \mathrm{E}-01$ & 3.33E-04 & $3.73 \mathrm{E}-02$ & $6.29 \mathrm{E}+04$ & $1.25 \mathrm{E}-01$ & $4.08 \mathrm{E}-03$ & $6.29 \mathrm{E}+04$ & $1.37 \mathrm{E}-02$ & $5.70 \mathrm{E}-05$ & $1.29 \mathrm{E}+04$ & $3.91 \mathrm{E}-05$ \\
\hline
\end{tabular}

Dose consequences are calculated as follows:

$$
\text { Dose }(\mathrm{Rem})=\mathrm{ST} \times \text { breathing rate } \times \mathrm{DCF} \times \chi / \mathrm{Q}
$$

Using appropriate values for each factor gives doses from uptake of Co-60 at $30 \mathrm{~m}$ for the facility worker, $100 \mathrm{~m}$ for collocated worker, and an assumed 5,000 $\mathrm{m}$ for the off-site public maximally exposed individual:

Breathing rate is the assumed breathing rate described in DOE O 440.1B. DCF is published in ICRP-68 for workers and ICRP-72 for the public. The airborne dispersion value for $\chi / \mathrm{Q}$ was obtained from RSAC-7 modeling using 95 percentile meteorological conditions appropriate for INL.

This analysis shows that dose to the collocated worker and to the public is negligible for this event. Evaluation guidelines are not challenged. 
INL/EXT-09-17427

Revision 0

\subsubsection{Natural Phenomena}

This event includes the primary natural phenomena hazards (NPHs) typically considered credible at the INL site such as: seismic, tornados, floods, range fires, snow loads, and lightning strikes. Other $\mathrm{NPH}$ events were considered as required by DOE Order 420.1B and DOE Guide 420.1-2 and were determined to be beyond credible, or the effects would fall within the effects of these primary hazards. Of these potential NPH events, high winds, fires, lightning strikes, and floods are assumed to have little or no impact on the underground concrete vaults, leaving seismic events as posing the greatest potential to impose structural loads sufficient to cause liner failure. A seismic event with sufficient energy to cause failure of the concrete vault and liner is EU. Even if such an event were to occur and the liner and vault were both to fail, it is probable that the failure would result in at least a partial filling of backfill sand and soil into the vault which would prevent a significant release of radiological material. Following the guidance of DOE-STD-1189 and in accordance with ANSI/ANS-2.26-2004, "Categorization of Nuclear Facility Structures, Systems, and Components for Seismic Design," the seismic event is categorized as SDC-1. Other NPHs and their impact on the Remote-Handled LLW Disposal Facility design will be evaluated in accordance with DOE-STD-1020-2002, "Natural Phenomena Hazards Design and Evaluation Criteria for Department of Energy Facilities," as applicable.

A severe seismic event is postulated to cause loss of shield plug integrity. Consequences to this postulated event are direct radiation exposure to a worker in the immediate vicinity of a failed shield plug. The shield plugs to be used are robust and placed in a solid array over the entire waste disposal area. A strong seismic event is an assumed condition which could result in a failure of the 5-ft-thick concrete vault plugs. A seismic event with enough ground motion to fracture or rubbilize the vault plug is considered an extremely unlikely event. Other events which could potentially fracture a shield plug could not credibly cause the shield plug material to be completely removed and fail to provide shielding.

Dose to the facility worker in this case is assumed to be primarily from radiation exposure. Dose rates at contact with the waste liner can be as high as $30,000 \mathrm{R} / \mathrm{hr}$. Therefore, it is possible that a facility worker could be exposed to consequences of high radiation in the immediate vicinity of a failed shield plug. At the distance of the collocated worker at $100 \mathrm{~m}$ and the public at $5000 \mathrm{~m}$, dose rates would be negligible.

\subsubsection{External Events}

Events under this category of accidents include plane crash, vehicle crash, and adjacent building fire/explosion. Plane crashes on the INL are judged to be beyond extremely unlikely due to diversion of air traffic and based on air transportation safety information. Vehicle crashes and adjacent building fire/explosions do not have a significant impact on the liners buried at the Remote-Handled LLW Facility. There is no anticipated release of radioactive material from this category of accidents should they occur.

\subsection{Preliminary Selection and Classification of Safety SSCs}

Safety-class SSCs are hazard controls for which credit is taken, either preventive or mitigative, to meet the evaluation guidelines for the off-site public. In the accident cases evaluated for the RemoteHandled LLW Disposal Facility, evaluation guidelines for the public are not challenged for unmitigated releases. Therefore, no safety-class SSCs are identified or required for this facility.

Safety-significant SSCs are hazard controls for which credit is taken to prevent or mitigate postulated anticipated or unlikely accidents that could result in consequences to collocated or facility workers exceeding $25 \mathrm{rem}$. In the worst case design basis accident identified for the Remote-Handled LLW Storage Facility, it is concluded that the potential exists for an accident which could result in dose 
consequences exceeding these guidelines to the facility worker. The 5-ft-thick concrete shield plugs are identified as a component which would protect the facility worker from those consequences. The shield plugs may, therefore, be designated as safety-significant SSCs for design and facility planning purposes. As the facility design matures, further analyses will be performed evaluating the direct radiation exposure to the facility worker from specific material being stored.

The primary mechanical system of the facility is related to operation of the hoisting system associated with the working platform that is used to lower the NRF waste liners into the vaults. The system currently used is owned by the Office of Naval Reactors and is planned to be transferred to the new disposal facility for use in waste placement operations. This system has not been designated as a safety SSC for handling the NRF activated metal waste. Since the waste stream is the same and handling operations will be similar in the proposed new facility, it is not expected that the safety designation would change. Preliminary dose calculations made for a single waste liner also supports this position. Development of other liner transfer systems will need to ensure that all applicable mechanical systems are designed using the appropriate protocols. Any ancillary equipment specifically required to interface with the liner for transport and unloading, other than the typical hoisting and rigging components, will be provided by the generating facility.

The pre-cast concrete storage vaults are considered defense-in-depth design features and perform the safety function of shielding and confinement; however, they are not derived as safety-significant. The vaults are located below ground surface, isolating contents from facility workers, and, upon failure, would not impose any risk of fatality or serious injury to workers. There are no failure scenarios for the vaults that result in a loss of function in an emergency that may be needed to preserve the health and safety of workers. Furthermore, in the improbable event of vault or shield plug failure, there would be no significant offsite consequences.

Based on an initial review of the applicable facility hazards and in accordance with Section 4 of ANSI/ANS-2.26-2004, the Remote-Handled LLW Disposal Facility seismic design category will be SDC-1. This determination is based on the assumption that a failure of a vault will not cause radiological material to be brought to the surface and that it will remain in place without causing significant radiological exposure to workers, the public, or the environment. As stated in the standard, no Limit State identification is required for SDC-1 systems, and the seismic evaluation on the facility will be performed in accordance with the International Building Code (IBC 2009).

\section{SECURITY HAZARDS AND DESIGN IMPLICATIONS}

The waste stream destined for the proposed Remote-Handled LLW Disposal Facility is classified as remote-handled LLW. The waste contains little fissionable material and poses little or no risk of criticality or diversion. Based on the characteristics of the remote-handled LLW, the facility (as proposed) will require at most a property protection area (perimeter fence) as security controls.

The facility will be equipped with a security system that includes remote visual capabilities and wireless alarms that can be monitored at an offsite location. This system will be comprised of a camera network that will monitor the access gate to the facility and other locations as warranted. The network signals will provide remote video surveillance and indications of when the facility gate is open and closed at a monitoring location determined by the INL security organization. This system should be equipped with eight hours of backup power.

Insider threats and sabotage risks are similar in nature to the current operational portfolio in place at RWMC. Therefore, the security impact of the Remote-Handled LLW Disposal Facility should have minimal additional impact to the existing INL security program and should be consistent with current 
practices and operational risks at RWMC. Based on an initial review of the proposed operations in relation to ongoing disposal operations at the RWMC, analyses are expected to focus on radiological sabotage events associated with transport and disposal of the remote-handled LLW waste streams.

NRF-generated remote-handled waste that is currently disposed of at RWMC and will be disposed at the proposed facility is generally classified due to classified shapes. The liners are bolted shut and are considered self-protected due to the high contact radiation levels. Continued management of NRF classified waste in this manner is planned and has been approved by the Naval Reactors Laboratory Field Office. Other waste streams identified for disposal at the proposed facility do not contain classified material.

A formal review will be conducted, based on the final design and location of the facility to validate the foregoing conclusions and to determine if additional security concerns exist based on material types and quantities. This analysis will be conducted before the start of operations to ensure adequate security measures are in place and operational. Security requirements that may be imposed are not anticipated to impact the facility safety basis, and any such additional security measures should not introduce additional hazards.

Consistent with DOE Order 420.1B, facility design will accommodate all requirements for safeguards and security, access control, and emergency egress. Where conflict occurs between such requirements, life safety requirements have precedence. As designed, this facility complies with the letter and intent of the order and presents no risk to employees with respect to NFPA 101, "Life Safety Code."

\section{NUCLEAR SAFETY DESIGN CRITERIA}

\subsection{Approach for Compliance with Design Criteria}

DOE Order 420.1B provides attributes to which design criteria may be compared to ensure that DOE nuclear facilities are constructed in a manner that will protect the public, workers, and the environment from nuclear hazards. Applicable criteria from DOE Order 420.1B are provided below.

- Integration of Design with Safety Analyses - Safety analyses will be performed during the appropriate phases of the Critical Decision process in accordance with DOE-STD-1189-2008. Those analyses will be used to identify hazards associated with the facility and the safety SSCs and the safety functions of those SSCs. Those analyses will be performed starting with preliminary analyses performed in the conceptual design phase CD-1 and progressively provide more detail as the design matures. At this point in the facility design, only the vault shield plugs have been designated as a safety SSC derived from accident analysis for hazards within the facility.

- Nuclear Facility Design - Design features for the Remote-Handled LLW Disposal Facility will include multiple layers of confinement for the material being stored. Defense-in-depth will include the concrete storage vaults and steel liners. The nature of the facility as an underground facility provides defense-in-depth protection. Control process will be identified for transloading the material from the casks to the storage vault locations. Lifting equipment will be managed in a way to maintain safe lifting operations. Worker safety will be enhanced through the use procedures, safety management programs, qualification and training programs, ALARA programs, and equipment measurement and testing requirements. The use of shielded casks under proper administrative controls provides defense-in-depth protection to the facility operations. 
- Fire Protection Program - The waste streams identified for disposal in the proposed Remote-Handled LLW Disposal Facility contain very little combustible material. An evaluation will be performed and documented to assess the need for fire protection programs and systems as part of development of the PDSA.

- Nuclear Safety Considerations - Further evaluation will be made on the need for criticality safety requirements (i.e., specific packaging configurations for high fissile materials) pertaining to the proposed Remote-Handled LLW Disposal Facility during development of the PDSA.

- Natural Phenomena Mitigation Design-Facility components will be designed, constructed, and operated in a manner that will withstand NPH and ensure that the safety function of each system or component will remain viable. For most NPH events, the facility consequences are very low due to the vaults being placed in the ground where releases are very unlikely. A seismic study will be performed during development of the PDSA which will evaluate the effect of seismic events on the concrete vaults in particular.

\subsection{Exceptions to Design Criteria}

No exceptions to safety design criteria in DOE Order 420.1B have been identified for this proposed facility. In all cases, design criteria should be commensurate with the importance of the safety function performed and the needed reliability of that component or system.

\section{OTHER CONSIDERATIONS}

\subsection{Planned Studies or Analyses}

As the project design matures, generation of other safety documents and analyses will be required. These supporting documents, other than operational procedures, will include, as appropriate, a fire hazard analysis, a fire safety assessment, PDSA, DSA (DOE approval required) to supplement the INL's standardized DSA, hoisting and rigging plan, engineering design files, ALARA reviews, radiation work permits, operational job safety analyses, and industrial hygiene exposure assessments prepared in accordance with the associated INL procedures.

- $\quad$ Seismic Evaluation-Damage from seismic events results from differential movement in a structure. Because of the decoupled nature of the vault system, in that each of the storage vaults is independent of the other vaults, the facility is characterized by numerous small structures rather than a single large structure. The relatively compact size of each vault, the design and materials of construction, and placement method (installed entirely in soil and never in bedrock) make it improbable that seismic motion of adjacent soils could generate forces sufficient to damage a storage vault. A structural evaluation of the proposed vault system should, however, be performed that addresses the capability of the vaults to withstand the loads and forces as defined in applicable guidance from the IBC. The evaluation should include the effects of differential displacement, mechanical loading (i.e., horizontal and vertical vibration of the vault and waste liner stored within), and seismic excitation of the soil in which the vaults are set. The results of the evaluation should indicate whether the seismic-induced differential displacement is a concern for the vaults and will be used in making the final hazard categorization. A seismic study will be performed during development of the PDSA which will evaluate the effect of seismic events generally and on the concrete vaults in particular. 
- Criticality Evaluation - The need for a criticality study will be evaluated in a later phase of the facility design. In the conceptual stage of the facility, preliminary evaluations indicate that the waste streams for the facility do not contain significant quantities of fissionable material to make nuclear criticality a credible accident. The need for a criticality evaluation will be performed during development of the PDSA.

- Dose Evaluations - The DBAs noted in this document were qualitatively evaluated in order to determine magnitude of postulated accidents involving release of radioactive material or direct exposure to high radiation levels. These results are considered preliminary and should be followed up with more complete and rigorous analyses. The evaluations should consider probable MAR from IWTS waste and container profiles. Likewise, direct radiation exposure analyses are preliminary in this report. As the design is developed and new liner configuration completed, more detailed analyses can be modeled. Further dose consequence evaluations will be performed during development of the PDSA.

- Vulnerability Assessment - Security hazards will be better understood upon completion of an assessment of the risks associated with disposal of this material. Based on an initial review of the proposed operations in relation to ongoing disposal operations at the RWMC, analyses are expected to focus on radiological sabotage events associated with transport and disposal of the remote-handled LLW waste streams. This assessment is tied closely to facility siting and, therefore, will be prepared following identification of a proposed siting location.

\subsection{Safety-in-Design Risks and Opportunities}

The project risk management plan (PLN-2541, "Risk Management Plan for the Remote-handled Low-level Waste Disposal Facility Project") defines the scope, responsibilities, and methodology for identifying and evaluating impacts of and managing risks that could affect successful completion of the project. The objective of the risk management plan is to enable project success by identifying project risks, including programmatic, technical, cost, and schedule risks, and appropriate response actions to effectively manage the risks through project completion. The highest ranked risk from PLN-2541 is the decision whether or not the facility will be underlayed with an impervious liner. Significant cost and schedule impact could occur as a result of increased design requirements, more complex construction (e.g., liner and monitoring systems), and regulatory coordination. Given the constraints of the planned schedule, any delay could result in the inability to maintain continuous disposal capability for remotehandled LLW, adversely impacting both the project and the waste generators' abilities to fulfill their respective missions. The use of an impervious underlayment could impact the risk of an analyzed accident of corrosion-induced waste liner failure. Trapped environmental water could increase the likelihood of that event. A decision to include an impervious liner could also result in fundamental changes to facility design, which could impact completed and planned nuclear safety analyses and documentation.

Other risks related to the safe design of the facility involve the validation of assumptions used in calculations and analyses associated with this CSDR. Preliminary hazard categorization and performance of preliminary accident identification and consequence analyses were made using assumptions and information obtained from the project conceptual design report and other facility documents reflecting this stage of conceptual design. The assumptions used in these evaluations were understood to be conservative. If those assumptions changed or were found to be non-conservative, results of the analyses could change. The risk associated with a change in assumptions is the possibility that previously unidentified safety SSCs could be identified if the analyses changed significantly. 
Safety SSC derivation is based on evaluation of accident conditions. Evaluation of accidents in this facility did not derive the need for casks to be designated as safety-class or safety-significant. It is clear that the use of casks is important, especially during normal operations, in protecting the facility worker. There is a risk that the safety designation of the shielded casks or CVAS would be raised to safety-significant.

In summary, the program risks identified in PLN-2541 are primarily associated with successful completion of the facility rather than of a technical nature for storing waste in below-ground vaults and the design features that are needed. Overall, the programmatic risk is that the facility would not be built, or would not be operational by the target date. The consequence of this risk would be significant impact on Naval Reactor (NR) and Department of Energy Office of Nuclear Energy (DOE/NE) programs, which rely on a clear disposal path for remote-handled LLW. Other risks are in performance of evaluations on which design criteria will be established. New findings could result in revised dose consequence evaluations potentially identifying new or higher-classed SSCs.

An opportunity that will require evaluation during the design phase of the project will be the final hazard categorization of the facility based on facility segmentation. This will be based on an evaluation of alternate release fractions and on the results of the seismic analysis evaluation that will also be performed. The outcome of these evaluations may result in an opportunity to downgrade the facility hazard category.

\subsection{Lessons Learned From Previous Experience Involving Major Systems}

The proposed Remote-Handled LLW Disposal Facility will be designed and constructed similar to the remote-handled LLW concrete disposal vaults currently in use in the RWMC SDA. This will accommodate, to the maximum extent possible, uninterrupted operations at the generating facilities and will capitalize on the operations experience and cost-efficiencies of current remote-handled LLW disposal practices. At this stage of the proposed facility design, preliminary analyses of postulated accidents do not derive the need for safety SSCs.

\section{REFERENCES}

29 CFR 1910.119, "Process Safety Management of Highly Hazardous Chemicals," Code of Federal Regulations, Office of the Federal Register, August 2006.

ANSI/ANS-2.26-2004, "Categorization of Nuclear Facility Structures, Systems, and Components for Seismic Design,” American National Standards Institute/American Nuclear Society, December 2004.

DOE-HDBK-3010-2004, “Airborne Release Fractions/Rates and Respirable Fractions for Nonreactor Nuclear Facilities," U.S. Department of Energy.

DOE/ID-11364, "Mission Need Statement for the Idaho National Laboratory Remote-Handled Low-Level Waste Disposal Project," June 2009

DOE O 420.1B, “Facility Safety,” U.S. Department of Energy, December 2005.

DOE O 435.1, "Radioactive Waste Management," Change 1, U.S. Department of Energy, July 1999.

DOE O 440.1B, “Worker Protection Program for DOE,” U.S. Department of Energy, May 2007. 
INL/EXT-09-17427

Revision 0

DOE O 5400.5, "Radiation Protection of the Public and the Environment," Change 2, U.S. Department of Energy, January 1993.

DOE G 420.1-2, "Guide for the Mitigation of Natural Phenomena Hazards for DOE Nuclear Facilities and NonNuclear Facilities," U.S. Department of Energy, March 2000.

DOE-STD-1020-2002, "Natural Phenomena Hazards Design and Evaluation Criteria for Department of Energy Facilities," U.S. Department of Energy, April 2002.

DOE-STD-1027-92, "Hazard Categorization and Accident Analysis Techniques for Compliance with DOE Order 5480.23, Nuclear Safety Analysis Reports," U.S. Department of Energy, September 1997.

DOE-STD-1189-2008, “Integration of Safety into the Design Process," U.S. Department of Energy, March 2008.

ICRP-68, "Dose Coefficients for Intakes of Radionuclides by Workers," International Commission on Radiological Protection, 1994.

ICRP-72, “Age-dependent Doses from Intakes of Radionuclides,” International Commission on Radiological Protection, 1996.

INL/EXT-07-12902, Siting Evaluation for Remote-handled Low-level Waste Disposal Facility, Idaho National Laboratory, Rev. 0, February 2008.

INL/EXT-07-12903, Preliminary Hazard Assessment for the Remote-handled Low-level Waste Disposal Facility, Idaho National Laboratory, Rev. 2, February 2010.

INL/EXT-09-17152, Remote-handled Low-level Waste Disposal Project Alternatives Analysis, Idaho National Laboratory, Rev. 0, November 2009.

NFPA 101, “Life Safety Code,” National Fire Protection Association, 2006.

NS-18101, “INL Safety Analysis Process,” Idaho National Laboratory, Rev. 3, May 2008.

NS-18104, “Nuclear Safety Engineering,” Idaho National Laboratory, Rev. 5, May 2009.

PLN-2541, "Risk Management Plan for the Remote-handled Low-level Waste Disposal Facility Project," Idaho National Laboratory, Rev. 1, October 2009. 